\title{
Opening up the Coast
}

\author{
Citation: \\ Rumson, A.G. and Hallett, S.H (2018) Opening up the coast. Ocean \& Coastal Management, \\ Volume 160, 15 June 2018, 133-145. doi.org/10.1016/j.ocecoaman.2018.04.015.
}

\begin{abstract}
Coastal zones attract human settlement, business and industry, and are instrumental to the functioning of societies both in coastal states and the wider global community. However, the oceans and coasts are under growing pressure as human practices change, populations rise and climate change impacts increase. In managing coastal regions, high quality data forms the basis of rational decision-making. Large volumes of 'triple bottom line' data exists representing a wide variety of environmental, social, and economic themes in coastal regions. Such data is especially crucial to development of environmental risk evaluations for the coast. The momentum driving the Open Source data movement across the world is accelerating and consequently, huge quantities of data are becoming freely available to the public. This presents a valuable opportunity for coastal managers, policy makers and land planners, who need to evaluate the full implications of their choices. Decision-makers frequently need to draw on many disparate datasets. However, this can be complicated by many factors, including a lack of awareness of the full range of datasets available. This paper seeks to explore this area, taking the UK as an example, to reveal how currently available open data sources relate to coastal management decision-making. Environmental risk management is a cross-cutting theme, relevant to all areas of coastal management. As such, this topic is discussed and addressed within a case study focusing on the vulnerable coastal region of East Anglia. In collation and analysis of coastal data Geographical Information Systems (GIS) can play an important role, in line with this GIS approaches were utilised within the case study. The case study led to development of a conceptual framework which can be applied to future coastal risk assessments, using Open Source data. The UK is currently at the forefront of the Open Source data movement and as such it is used as an example within this paper, however the issues addressed have international relevance, and the UK perspective is used to illustrate wider opportunities, resulting from freely available data sources, extending to management of coastal regions globally.
\end{abstract}

Author: Alexander Rumson a and Stephen $\mathrm{H} \mathrm{Hallett}^{\mathrm{a}}$

Affiliations - all authors

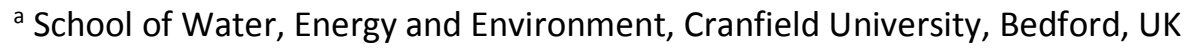

Corresponding Author:

Alexander G. Rumson, School of Water, Energy and Environment, Building 53, Cranfield University, Bedford, MK43 OAL, UK

Email: al.rumson@cranfield.ac.uk

Key Words: Open Source data, Coastal Management, Geographical Information Systems (GIS), Environmental Risk 


\section{Introduction}

Coastal regions are home to the majority of the Earth's population and therefore 'much of the world's economy, is at least partly dependent upon the health and integrity of coastal resources' (Misdorp, 2011, p.9). Coastal zones provide jobs, ports, recreation areas, energy generation and ecosystem services, and have been ranked 'among the top places in the world in terms of population and value accumulation' (Kron, 2013). In recent times coastal regions have experienced 'amenity driven growth' (Roberts, 2012). Yet examples from across the world (such as highlighted by Cooper and Mckenna (2009)) indicate how economic growth has also produced negative impacts for sustainability in coastal zones, as settlements have formed in high risk areas (Cooper and McKenna, 2009). Such risk can be seen as the product of a high probability of a hazard event and the severe consequences which result (Kron, 2013; Nicholls et al., 2015; Filatova and Veen, 2006; Filatova et al., 2011; Dávila et al., 2014; Defra, 2009; Dodds, 2009; Defra, 2005; Evans et al., 2004; Viavattene et al., 2015). Consequences are generally calculated in relation to potential impacts (monetary damage and human casualties) (Filatova et al., 2011). The highest risk levels are generally experienced in locations having the highest concentration of people and value, and where there is a likelihood that a threatening natural event (for example a storm surge) may occur (Kron, 2013). Coastal hazards are normally associated with 'weather hazards', the most common being the storm surge, which can inundate low-lands (Deeming, 2008). Pollution represents another significant consequence of increased human usage of the marine environment. Rodwell et al. (2014) draw attention to prominent public concern over land-based industries polluting the marine environment. Threats presented by high levels of pollution and seawater inundation are both exacerbated by catalyst factors such as climate change, increasing coastal population densities, and resource depletion. These factors can result in the consequences to humans and the environment being both more severe and extensive.

The process of managing coastal resources is fraught with challenges, due in part to the coast being an interconnected domain where stakeholders and users have competing interests which, invariably, do not align with optimal, sustainable solutions for regions. The role of data, information and knowledge within the process of coastal management is paramount. In line with the increased availability of datasets relating to the coast, 'data' has thus become a prominent theme of discussion within academe and the coastal management community. This has influenced approaches taken by governments in managing risk on the coast. In the 2000s coastal governance arrangements were often in flux (Fataleeva, 2011 in Nicholls et al. (2015). In many countries, changes occurred mirroring those in England, where the dominant approach of installation of hard adaptation measures (Mokrech et al., 2011) and maintenance of the current extent of sea defences, was recognised as unsustainable (Cooper and McKenna, 2009). Publications such as The Foresight Future Flooding report (Evans et al., 2004), exemplified a shift to a holistic, whole-shoreline approach to understanding and addressing coastal risk (Environment Agency, 2010). Yet it is argued that a disconnect still exists between scientific evidence and decision-making at a supranational level, such as within the European Union (Dodds, 2009). Nevertheless Open Source data initiatives are now seen to be 'transforming the availability and ease of access to high quality public sector data' (Smith, 2016), acting as a driver for increased utilisation of such data by coastal decision-makers. This is aided by the ability to collate and manage these diverse datasets using tools such as Geographic Information Systems (GIS). Access to many datasets, relevant to coastal management, is provided online in the form of web-services, which can be accessed in real time, reducing requirements to download and store data locally. This paper further seeks to raise awareness of the range of Open Source datasets available related to the themes of coastal management (taking the UK as an example), revealing how these datasets can be drawn on in applications evaluating coastal risk. 
Within the domain of coastal management and maritime spatial planning, the requirement to embrace a process of evidence-based decision-making has been recognised (European Union, 2014), as opposed to prioritisation of the interests of those actors and organisations within society who wield power and influence. Access to information enables governments to make informed choices, and to explore alternatives. The requirement for information includes ecological, scientific, social and economic data (Kullenberg, 2010). This is recognised within a dominant coastal management process, being applied across the world, termed Integrated Coastal Zone Management, ICZM. ICZM encompasses a broad range of themes, and of these the threats posed by erosion and flooding represent a dominant focus of many coastal organisations, especially those within the case study site of this paper (East Anglia, UK). Yet coastal management covers a far broader remit than these issues alone. The broader themes outlined by England's Local Government Association Special Interest Group on Coastal Issues (The LGA Coastal SIG), (Table 1), provide a sound thematic basis to guide an understanding of these issues. This clearly illustrates the broad range of areas which coastal managers must contend with, and necessitates their drawing upon a wide-ranging variety of data sources, to generate an expansive knowledgebase. This paper expands upon these themes; Figure 1 relates these themes to Open Source coastal datasets, further illustrating how adoption of a thematic approach can enable freely available information relating to these topics to be easily located. Although the main examples drawn on in this paper relate to the UK, similar data sources exist within other countries, therefore the examples given are used to illustrate wider opportunities that extend to managing coastal regions globally.

Table 1: Themes covered by the LGA Coastal SIG position statements

\begin{tabular}{|ll|}
\hline \multicolumn{1}{|c|}{ Coastal Management Areas } \\
\hline 1. & Integrated Coastal Zone Management \\
\hline 2. & Energy \\
\hline 3. & Managing Fisheries \\
\hline 4. & Minerals and Dredging \\
\hline 5. & Ports and Harbours \\
\hline 6. & Marine Planning \\
\hline 7. & Waste Management \\
\hline 8. & Beach Management and Inshore Bylaws \\
\hline 9. & Coastal Access \\
\hline 10. & Marine Protected Areas \\
\hline 11. & Marine Pollution \\
\hline 12. & Coastal Regeneration and Economic Prosperity \\
\hline 13. & Coastal Adaptation \\
\hline
\end{tabular}




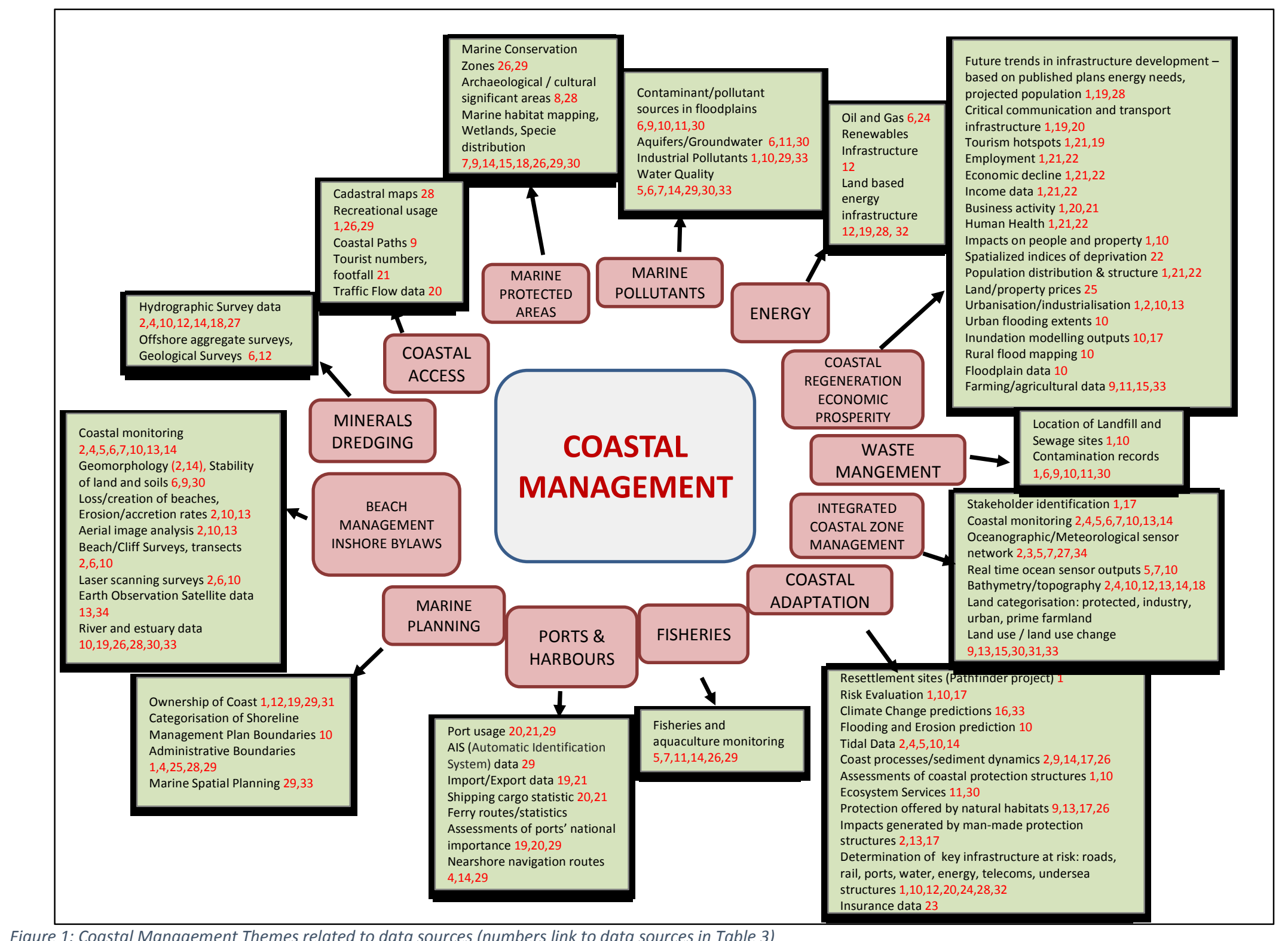




\section{Data use within coastal risk analysis}

Coastal datasets originate from a vast array of sources, the majority (90\%) of reported data collection for the coast of the UK being from publicly-funded sources (Dyer and Millard, 2002). This is data collected by the national government, environmental bodies, national mapping and charting agencies and government (sponsored) data collectors (such as universities, private companies, local authorities and non- governmental organisations). However, not all data collection relates to public projects. On the coast of East Anglia, for example, private data gathering is also frequently undertaken. One example of this is a bathymetric survey that Bourne Leisure group commissioned of the inshore area fronting a stretch of coast owned by the company in Suffolk. This formed part of their investment in private coastal defences (The Lowestoft Journal, MPC Marine Planning Consultants). Also, many highquality datasets are retained by energy companies, who have conducted independent surveys of inshore areas. The Crown Estate partially addresses this issue through a mandatory requirement for data and reports generated from renewable energy projects in UK waters, to be made available to the public after a specified period. The Crown Estate makes this information available to the public via its web portal, the 'Marine Data Exchange' (The Crown Estate). Beyond the UK there are many organisations who collect data and make this available at a regional and international level. NOAA (the National Oceanographic and Atmospheric Administration) (NOAAa) in the USA, is one such example; others from Europe being EMODnet (EMODnet), HELCOM (HELCOM) and OSPAR (OSPAR) (more details are provided of these organisations in the supplementary material, available online). In addition to this, global coastal datasets collected using Earth Observation (EO) satellites, are available for free, from sources such as Copernicus (Copernicus), who host a Marine environment monitoring service.

Evaluation of risk in coastal regions, is a process reliant on the availability of accurate information sources. Coastal datasets generally represent raw facts and figures, whereas processing of this data generates information outputs, usable in decision-making. This information can be further transformed to encapsulate understanding, which in turn can form the basis of knowledge (Anderson, 1991). Coastal risk calculations involve recognition of specific hazards present on the coast, broader coastal vulnerability, the potential impacts of these to society and the environment, and the role offered by adaptation measures. Given this, information needs to be acquired detailing past and existing occurrences of coastal hazards, as well as estimations of their future probability. Data relating to human activity and use of coastal regions is also essential, as this helps determine how vulnerable an area is (in anthropocentric terms) and the consequences which can result from the occurrence of hazard events. Table 2 identifies potential types of data and information that could be included in a risk evaluation relating to a given stretch of inhabited coastline. These data types are split between the data themes typified within the 'Triple bottom line approach' (Elkington, 1997), comprising environmental, social and economic themes. In ensuring that risk assessments are comprehensive and rigorous, it is necessary to adopt a heterodox/holistic approach to data collation and evaluation, drawing on data derived from many disciplines (including unconventional sources), to address both physical and human aspects of risk. The merits of this type of approach have been acknowledged in recent studies, such as the Tyndall Project (Mokrech et al., 2011). In this work, a wide variety of data variables were incorporated within simulation models, such as those relating to: marine conditions, extreme events, damage to persons and property, and socio-economic drivers. This contrasts with other, more conventional studies such as that conducted by Villatoro et al. (2014), which adopt a narrower focus, concentrating analysis on physical data, including detailed topographic and bathymetric data, and environmental modelling outputs. 


\begin{tabular}{|c|c|}
\hline Category & Data Type \\
\hline Environmental & 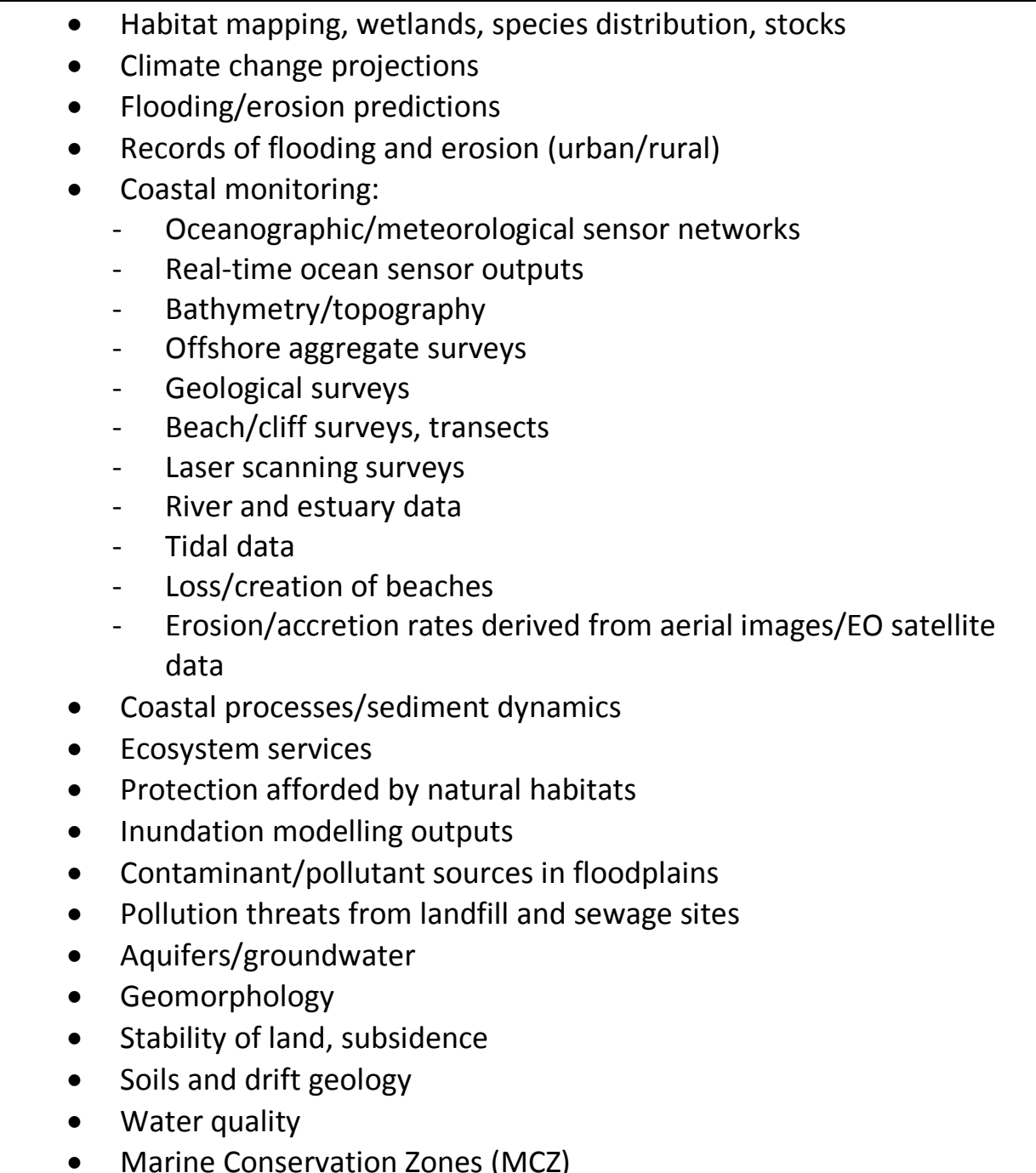 \\
\hline Social & 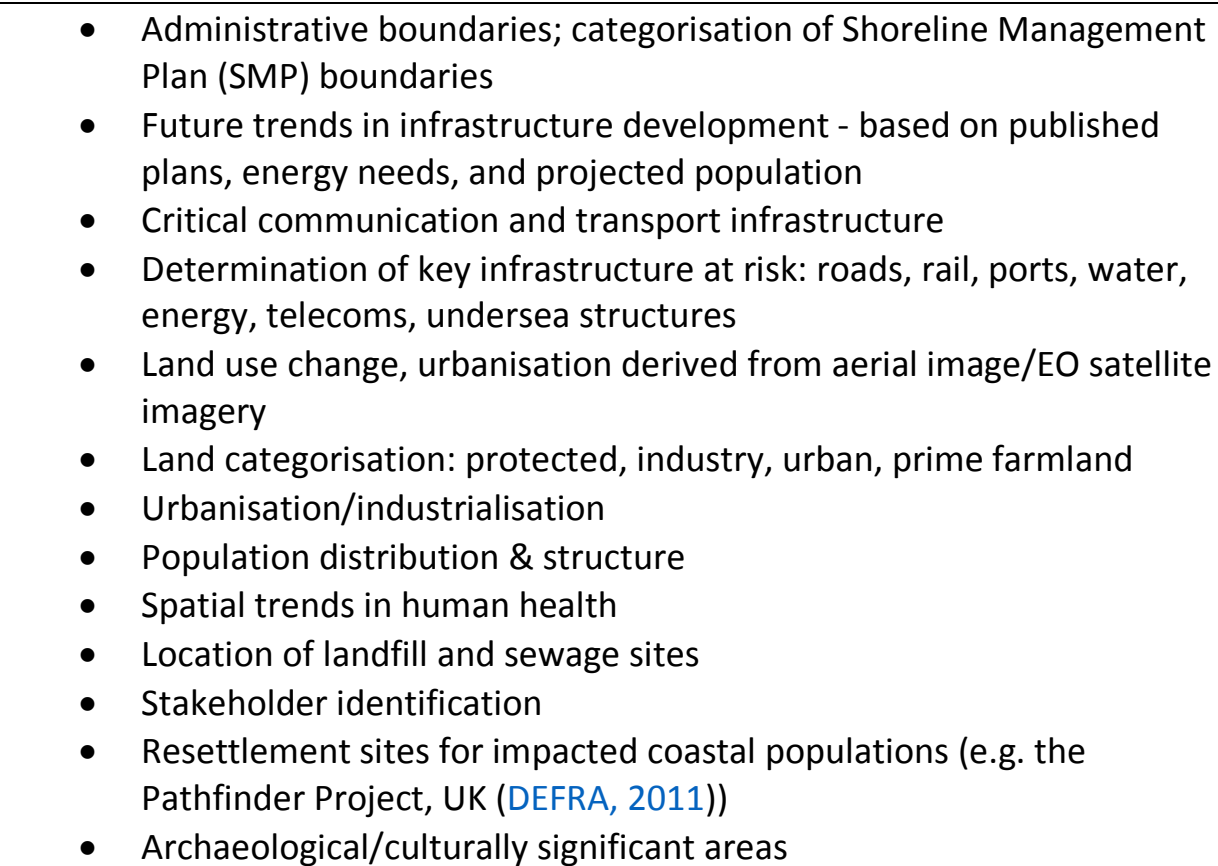 \\
\hline
\end{tabular}




\begin{tabular}{|c|c|}
\hline & $\begin{array}{l}\text { - } \quad \text { Cadastral maps } \\
\text { - Recreational usage of the coast } \\
\text { - Traffic flow data on roads }\end{array}$ \\
\hline Economic & $\begin{array}{l}\text { - } \text { Business activity } \\
\text { - Farming/agricultural data -crop yields } \\
\text { - Tourismeries and aquaculture - resources and revenue } \\
\text { - Financial impacts on people, property, business, government } \\
\text { - } \text { Assessment of coastal protection structures (condition and cost of } \\
\text { - } \text { Incomair/replacement) } \\
\text { - Employment } \\
\text { - Economic decline } \\
\text { - Spatialized indices of deprivation } \\
\text { - Oil and gas projects and infrastructure } \\
\text { - Renewable energy projects and infrastructure } \\
\text { - Ownership of the coast } \\
\text { - Port usage; assessments of a port's national importance } \\
\text { - Port import/export data } \\
\text { - Shipping cargo statistics; AlS data } \\
\text { - Nearshore navigation routes; ferry routes/statistics } \\
\text { - Land/property prices }\end{array}$ \\
\hline Multi- Category & $\begin{array}{l}\text { - Derived information from existing risk evaluations (environmental, } \\
\text { - } \quad \text { Macial and economic) } \\
\text { - Industrial pollutants (sources and impacts) } \\
\text { - Impacts generated by man-made coastal protection structures, change } \\
\text { of policy }\end{array}$ \\
\hline
\end{tabular}

Physical environmental data can represent parameters such as water temperature, shoreline sediment grain size, tidal range, pollution concentrations, river flows and topography. Such data is deemed distinct from socio-economic data (e.g. population distributions, and social groupings). Inclusion of Environmental data within analyses, is deemed a key requirement for the protection of human health and the avoidance of ecological disaster (Dyer and Millard, 2002). Infrastructure is a further key area of consideration in the evaluation of coastal risk. Flooding and erosion can generate direct and severe impacts on vulnerable infrastructure, creating more complex risk and indirect impacts to populations further afield. Interdependencies between infrastructures can further compound risks which arise. For example, the complex infrastructure systems underlying modern societies comprise many interdependent components (e.g. energy, water, transport and telecommunication networks). Changes in one component can destabilise the whole interconnected and interdependent 'system of systems', potentially resulting in catastrophic failure (Stapelberg, 2010). DEFRA (Defra, 2004) acknowledge this with respect to transport infrastructure, noting that consideration should be made in particular, of transport networks in relation to urban flooding. Other types of infrastructure noted, that may also be especially vulnerable to coastal hazards, include electricity supply, telecom networks (Penning-Rowsell et al., 2005) and aquifers (Lewsey et al., 2004). Environmental data can also be used to reveal impacts from storm surges on beach recession, and enable charting of areas flooded. By combining aerial photography with Lidar data, identification of low-lying areas vulnerable to flooding is made possible. A study undertaken by researchers at Durham University (Rosser et al., 2005), of a stretch of coastline in Whitby (UK) has successfully demonstrated how point cloud data generated by Lidar and terrestrial laser scanning, can be combined with other 
environmental data variables to increase understanding of coastal erosion and evolution, rock slope failure and wide-area ground deformation (Slatcher, 2017). When this data is further combined with demographic and socio-economic variables, such as land use, population densities and property valuations, it can reveal the consequences expected from the occurrence of such hazards, as well as particular 'hotspots' of combined concern.

\section{Open Source data}

A significant, concerted effort has been made in recent years to allow datasets held in the public domain, to become available as Open Source. Open Source data is increasingly being made accessible, through high quality Open Source data portals (Powrie et al, 2014). Governments across the world have sought to make public sector data, collected using tax revenues, available for private or commercial reuse. This has partially been driven by public demand (such as The Guardian's, Free our data campaign, in the UK (The Guardian, 2006). Private sector organisations are not usually required to make their data available as Open Source, however are compelled to do this in some cases, by a range of benefits this can bring. Organisations such as the Open Data Institute (ODI) (UK) (Open Data Institute), work with both public and private sector organisations to develop Open Source data opportunities, creating incentives for organisations to provide free access to their data.

The momentum of the Open Source data movement presents new opportunities, through widening access to information (Smith, 2016). This is being driven by a program to enhance information sharing between private and public-sector organisations (Ubaldi, 2013). It is exemplified by some of the larger government data portals such as: Data.gov (USA), Data.gov.uk (UK), Data.gov.au (The Australian Government), Canada's Open Government Portal (Government of Canada), Data.gouv.fr (France), and Data.go.kr (Korea). In June 2015, DEFRA (UK) set a target of making 8,000 datasets available Open Source within the next 12 months (GOV UK, 2017a). This target was exceeded, with over 10,000 datasets being ultimately released in the period (GOV UK, 2017b). Among those released were many high-resolution Lidar datasets covering UK coastal regions, published by the Environment Agency (EA). This momentum has contributed to the UK securing a leading position in the global Open Data Barometer rankings (World Wide Web Foundation). Today, much of the data required to build a risk evaluation matrix for coastal regions in the UK can be easily accessed and shared. The UK is in a privileged position in this respect, as the majority of this data was collected as a result of government funding, and recent requirements have resulted in this data being made available to the public (HM Government Cabinet office UK, 2012). This is unfortunately not the case for many other coastal states, which can lack publicly funded coastal monitoring programs or whose governments fail to place this information in the public domain. Many such states have been labelled 'data poor' (Rova et al., 2018; Lewis et al., 2013). The Open Data Barometer (World Wide Web Foundation) reveals that for the majority of low and middle-income countries Open Source data availability is poor. Unfortunately, this is especially a problem for Small Island Development States (SIDS) (Mackay et al., 2018), which invariably have highly vulnerable coasts.

The myriad of coastal datasets made available to download via Open Source portals presents opportunities for combining and analysing a diverse range of information, all now obtainable cost free. A listing of some of the organisational sources who host Open Source data portals containing data relevant to the UK coast is given in Table 3. The sources detailed in Table 3 are numbered, and within Figure 1individual coastal issues have been assigned corresponding numbers denoting potential data sources, from where related information can be found. This is also expanded upon within the supplementary material, available online. 
Table 3: UK Open Source data of key relevance in coastal management

\begin{tabular}{|c|c|c|}
\hline No. & Data Source & Examples of Data Types \\
\hline 1 & District Councils (accessed via Data.gov.uk) & $\begin{array}{l}\text { Local government held datasets: condition } \\
\text { surveys of coastal defences, land use change, } \\
\text { extent of habitation increases, socio-economic } \\
\text { variables }\end{array}$ \\
\hline 2 & The Channel Coastal Observatory (CCO) & $\begin{array}{l}\text { Archive and real-time coastal data, outputs } \\
\text { from academic studies }\end{array}$ \\
\hline 3 & The Met Office UK & $\begin{array}{l}\text { Meteorological data - frequency of extreme } \\
\text { events }\end{array}$ \\
\hline 4 & $\begin{array}{l}\text { UK Hydrographic Office (UKHO) (INSPIRE } \\
\text { Portal) }\end{array}$ & $\begin{array}{l}\text { Bathymetric charts, port and coastal data sets, } \\
\text { navigation routes, shipping traffic data }\end{array}$ \\
\hline 5 & British Oceanographic Data Centre (BODC) & $\begin{array}{l}\text { Biological, chemical, physical and geophysical } \\
\text { data }\end{array}$ \\
\hline 6 & British Geological Survey (BGS) & Geoscientific, geomorphological information \\
\hline 7 & CEFAS & Oceanographic data \\
\hline 8 & Historic England & Cadastral, listed data sets for the coast \\
\hline 9 & Natural England & $\begin{array}{l}\text { GIS digital boundary datasets, habitat mapping, } \\
\text { agricultural data }\end{array}$ \\
\hline 10 & The Environment Agency (EA) & $\begin{array}{l}\text { Coastal survey data: beach transects, } \\
\text { topographic and hydrographic surveys, the UK } \\
\text { national tide gauge network, flood risk } \\
\text { assessments, coastal management plans, data } \\
\text { on defences and intent, pollution }\end{array}$ \\
\hline 11 & $\begin{array}{l}\text { Department for Food and Rural Affairs } \\
\text { (DEFRA) }\end{array}$ & $\begin{array}{l}\text { Public sector food, agriculture and } \\
\text { environmental datasets }\end{array}$ \\
\hline 12 & The Crown Estate & $\begin{array}{l}\text { Maps, GIS data -offshore aggregates and } \\
\text { renewable energy project data }\end{array}$ \\
\hline 13 & Copernicus, ESA & Sentinel satellite data and derived outputs \\
\hline 14 & MEDIN & $\begin{array}{l}\text { Open source portal of marine environmental } \\
\text { data }\end{array}$ \\
\hline 15 & MAGIC & $\begin{array}{l}\text { Open source data repository relating to the } \\
\text { natural environment from across UK } \\
\text { government }\end{array}$ \\
\hline 16 & $\begin{array}{l}\text { Intergovernmental Panel on Climate Change } \\
\text { (IPCC) (IPCC) }\end{array}$ & $\begin{array}{l}\text { Climate, socio-economic and environmental } \\
\text { data, both past data and future scenarios }\end{array}$ \\
\hline 17 & $\begin{array}{l}\text { Academia (e.g. iCOASST (Nicholls et al., } \\
\text { 2012), RISC-KIT (van Dongeren et al., 2014), } \\
\text { FAST) }\end{array}$ & Coastal modelling output data and data centres \\
\hline 18 & EMODnet & European wide marine datasets \\
\hline 19 & Data.gov.uk (web portal) & Links to all public available government data \\
\hline 20 & $\begin{array}{l}\text { Department for Transport (DFT) UK and } \\
\text { Highways England }\end{array}$ & Traffic flow data \\
\hline 21 & The Office for National Statistics (ONS) & $\begin{array}{l}\text { UK national population, business and industry } \\
\text { statistics }\end{array}$ \\
\hline 22 & Datashine UK (University College London) & $\begin{array}{l}\text { Spatial representations of socioeconomic } \\
\text { datasets taken from UK } 2011 \text { Census data, by } \\
\text { University College London (UCL) }\end{array}$ \\
\hline 23 & Association of British Insurers (ABI) & $\begin{array}{l}\text { Insurance data downloads (limited Open Source } \\
\text { Content) }\end{array}$ \\
\hline 24 & UK Oil and Gas Authority (OGA) & $\begin{array}{l}\text { Oil and gas fields, reserves, seismic surveys and } \\
\text { seabed infrastructure }\end{array}$ \\
\hline 25 & HM Land Registry & Land and property information/prices \\
\hline
\end{tabular}




\begin{tabular}{|l|l|l|}
\hline 26 & Joint Nature Conservation Centre (JNCC) & $\begin{array}{l}\text { Biodiversity and species data, Mapping } \\
\text { European Seabed Habitats (MESH), marine } \\
\text { survey data, MCZs }\end{array}$ \\
\hline 27 & NOAA NCEI & Global datasets for coasts and oceans \\
\hline 28 & Ordnance Survey (OS) & Cadastral survey map data \\
\hline 29 & Marine Management Organisation (MMO) & $\begin{array}{l}\text { Marine planning, fisheries, licencing, protected } \\
\text { areas, coastal recreation }\end{array}$ \\
\hline 30 & Centre for Ecology and Hydrology & $\begin{array}{l}\text { Hosts the National River Flow Archive (NRFA), } \\
\text { Environmental Information Centre, } \\
\text { Environment change network, and the } \\
\text { biological records centre }\end{array}$ \\
\hline 31 & The National Trust & $\begin{array}{l}\text { Coastal land use and land access to National } \\
\text { Trust land }\end{array}$ \\
\hline 32 & National Grid & Energy Infrastructure \\
\hline 33 & European Environment Agency & Europe wide Environmental data downloads \\
\hline 34 & CEDA Data Archive & Atmospheric and Earth Observation data \\
\hline
\end{tabular}

One driving force behind moves towards standardising and sharing data is the EU INSPIRE Directive (2007/2/EC) (The European Commission), which was envisioned to improve access, sharing and discovery of public sector data. The INSPIRE Directive was implemented by the EU in 2007, seeking to establish a Spatial Data Infrastructure (SDI) across European member states. The Directive applies to public sector organisations, and other organisations on a voluntary basis. Common Implementing Rules (IR) are required in areas such as: metadata, data specifications, network services, data and service sharing, monitoring and reporting. Within this, the problem of duplication of data has been identified specifically. The Marine Environmental Data and Information Network (MEDIN), a UK data repository for marine environmental data, has adopted the INSPIRE Directive, especially in relation to metadata standards (Rodwell et al., 2014). MEDIN datasets are stored in a disaggregated, 'shared or distributed' manner, which corresponds to the INSPIRE objective of permitting disseminated data stores using web services. Within the domain of coastal management, as in many other sectors, data is not contained 'centrally' by any one organisation. Following the principles of INSPIRE, data can be collated dynamically from multiple sources using standardised formats and transport mechanisms (such as REST, WFS/ WMS/WCS web services). In addition to enabling access to data, this can provide wider benefits to the data user community, in that it permits the relevant data 'owner' to retain the responsibility for their data and its maintenance, as well as the technological mechanisms to share it efficiently with others. Key to this process is the creation and enforcement of appropriate metadata standards, to ensure knowledge of the data is disseminated alongside the data itself. If data is accessed through web services, this allows important updates and changes to data (made by the data owner), to be incorporated within third party use of this data. This can ensure that the most up-todate information, is continually used within projects. Given this, for many data sources, which may be incorporated in wider services, it is preferable to access these via web services as opposed to downloading and hosting the data from an in-house server.

Advances such as the shift towards Open Source data do result in specific challenges. Restrictions on the use of datasets and intellectual property remain a potential area of concern. This corresponds to the emergence of a new generation of Open Source intellectual property rights terms. A range of these now exist, such as the 'Open Government Licence' (OGL) (The National Archives), used by UK public sector bodies such as DEFRA. Another significant issue relates to 'user understanding' of the available data, e.g. omissions, assumptions made, methodologies used, precision and other caveats. Clear limitations are imposed on datasets due to data collection methods and accuracies achieved. Many datasets, such as Lidar topography and sonar bathymetry, which have been acquired over different time periods, vary considerably in spatial density of data points and relative accuracies of data 
collection techniques. Direct comparisons between such datasets must therefore be approached with caution. Additionally, downloading datasets for larger geographical areas and time periods can prove more complex and time consuming (depending on which Open Source data portal is used). Another significant constraint imposed on the use of Open Source data, especially important when considering data from a range of different countries, is standardisation of data formats, which can reduce requirements to clean/process data before it becomes usable. This is a challenge which flood modelling companies, who generate flood risk evaluations for multiple countries, frequently contend with. Organisations have emerged which attempt to tackle such challenges, including Oasis Hub (2018), which provides Open Source environmental data from different sources, but in a more standardised format.

Notwithstanding these issues, the shift towards Open Source data goes some way to addressing widespread demands for data sharing and standardisation. For example, many such as Rodwell et al. (2014, p.253), have argued that 'more effort is needed to standardise or harmonise access to data within the UK and Europe'. This remains an issue that many public-sector bodies (such as those listed in Table 3) are now tackling directly through Open Source initiatives. One crucial means to enable greater understanding of these datasets, and reduce errors in their use, is to ensure that comprehensive metadata is supplied with the data; this being descriptive data detailing data provenance and providing guideline on use of the data. Standards such as ISO19115 have been adopted as a basis for such descriptive records (Keay et al., 2009). In accordance with the INSPIRE Directive, this should enable, data source, quality, age and original format to be determined.

\section{Open Source Data Sharing and Mapping for the Coast}

An ever-increasing number of collaborative projects seek to bring spatial datasets together for marine and coastal areas, making this data available to the public via Open Source portals and web-mapping tools. Details of a selection of these are provided in the supplementary material to this paper. Within the UK, the Marine Environmental Mapping Program (MAREMAP), the Multi-Agency Geographic Information for the Countryside (MAGIC) and MEDIN are examples of this kind of initiative. Aside from the collaborative Open Source data portals, numerous individual organisations make their datasets freely available to the public. Many of those who provide data related to coastal areas in the UK are listed in Table 3. Beyond the UK, the availability of Open Source data varies considerably depending on location. In the USA, a large number of portals exist making coastal datasets available to the public, such as those hosted by NOAA (NOAAb) and the US Geological Survey (USGS). A pan-European initiative called SeaDataNet (http:// www.seadatanet.org), provides ocean and marine data for European Seas. Other data sharing/mapping projects of note, which are underway across Europe include HELCOM for the Baltic, and OSPAR for the North Atlantic. A wider initiative for Europe, including the UK, is the European Marine Observation and Data Network (EMODnet). On a global scale NOAA have established a National Centre for Environmental Informatics (NCEI) (NOAAa). Other global initiatives are the Ocean Biogeographic Information System (OBIS) (IODC UNESCO) and the Marine Geoscience Data System (MGDS) (Columbia University).

The wide variety of open data sources provide a valuable resource to coastal research projects. For example, the Tyndall project has combined data successfully, from many of the sources detailed (Table 3), in the coastal models it created for East Anglia (Mokrech et al., 2011). In the component of their study focusing on the coast of Devon (England), Villatoro et al.(2014) drew on datasets from the BODC and from the National river flow archive. In creating flooding maps, Villatoro et al. also combined Lidar data from the CCO, with geospatial data from EDINA DIGIMAP (an academic source of geospatial data). This work also drew on a repository of re-analysis data to permit generation of future scenarios. Conventional geospatial point cloud data and satellite derived imagery are deemed especially useful when creating coastal models and, as such, should form a key part of vulnerability 
assessments. Sources of such data include the EA (Data.gov.uk), Copernicus (Copernicus) and the CCO (Channel Coastal Observatory).

\subsection{Earth Observation (EO) satellite data}

A key source of wide-area coverage geospatial data, of growing importance, derives from satellite EO data. Remote sensing has long provided a basis for terrestrial, atmospheric and marine monitoring, and geo-positioning, GNSS services. However, the growing range of satellite and airborne platforms, now available with increasing spatial resolution, spectral discrimination and overflight return periods offers a range of new opportunities. This is combined with the corresponding availability of much of this data as a free and Open Source resource. Consequently, contemporary coastal management tools will increasingly incorporate remote sensed data and related thematic interpretations. Examples of satellite platforms providing access to free data include Landsat, EOS MODIS, Terra EOS ASTER, and the associated Space Shuttle Topography Mission (SRTM). The Foreshore Assessment using Space Technology (FAST) project is a good example of an initiative which has incorporated Open Source EO data for coastal regions, through tools such as Google Earth Engine. This has enable estimates to be derived, for example, of loss and gain of natural capital acting as a buffer in coastal areas. Work completed in the project can be viewed through the MI-SAFE tool (fast.openearth.eu) and their datasets are made available Open Source, accessible via web-services.

Perhaps the most significant provider of Open Source satellite data has arisen via the Copernicus programme. This is managed by the European Commission, and delivered by the European Space Agency (ESA), the European Organisation for the Exploitation of Meteorological Satellites (EUMETSAT), the European Centre for Medium-Range Weather Forecasts (ECMWF), related EU Agencies and Mercator Océan. The Copernicus programme comprises six Sentinel satellites currently in service, plus a growing range of fixed in-situ data and services (www.copernicus.eu). To aid the uptake of the data from the Copernicus programme, a range of interpreted thematic data services are available alongside the raw satellite data. These currently or shortly, addressing atmospheric (CAMS), marine (CMES), land (CLMS), climate (C3S), emergency (EMS) and security themes. Each theme comprises substantive data offerings, regularly updated, for a range of parameters of relevance. By example, for the Copernicus Marine Environment Monitoring Service (CMEMS), the 46 variables encompass measures of sea temperature, salinity, surface height, mixing, ice levels, wind and wave assessments, dissolved oxygen and nutrients, plankton levels and primary production, assessments of sea reflectance, transparency and turbidity. Each thematic data service is delivered by a dedicated web portal, e.g. marine.copernicus.eu/services-portfolio/access-to-products/.

\subsection{Advances in coastal risk mapping}

The exponential growth in the extent and range of datasets related to the coast, and their increasing availability as Open Source provides a key driver for comprehensive, advanced risk-mapping projects for coastal regions. Another driver is the rapid advance in data collection, storage and processing technologies. New remote sensing datasets are noted to reduce uncertainty significantly (Brown, 2006). Recent advances in the field of remote sensing have resulted in increased data density, return period and spatial coverage, enabling visualisation and monitoring, at scales not previously possible. Improvements in measurement, observation and the establishment of extensive communication networks can act together to increase understanding of physical processes, leading to more effective early warning systems being created, such as that implemented in Emilia-Romagna, Italy (Harley et al., 2016). However, such innovations are not confined solely to an ability to monitor environmental variables. Hazard management has been reported to have moved from an early focus on physical hazards alone to an approach incorporating 'socio-economic, political and behavioural patterns of the affected population' (Dávila et al., 2014, p.183). This creates a requirement to combine wide varieties and volumes of data, originating in many different formats. Coupled to this, new advanced sensor technologies such as Lidar and satellite remote sensing, generate high volumes of data. Additionally, 
increasing quantities of data are made available as 'real-time feeds', such as those relating to ocean sensor data, provided by, for example, CEFAS and the CCO.

Given these recent progressions in the field of coastal data, the most up-to-date computing technologies need to be utilised to enable comprehensive, geospatial risk evaluation tools to be created. The rapidly developing field of Geographical Information Systems (GIS), provides one potential solution to these challenges. In the case study example which follows, GIS has been utilised to enable large volumes of Open Source coastal data to be collated, visualised and analysed. The aim of this was to enable fresh insight to be derived from what initially appeared an overwhelming mass of data.

\section{Case Study: Open Source data revealing coastal risk in East Anglia}

\subsection{Coastal Management Challenges in East Anglia}

Numerous coastal risk adaptation issues in East Anglia have been introduced, and it is this English region that is selected as a case study for this paper (see Figure 2). East Anglia's coast has been recognised as highly vulnerable (Nicholls et al., 2015; Brooks and Spencer, 2010), yet a wealth of information relating to coastal processes exist for the area. The Suffolk and Norfolk coast is characterised by low lying land (Figure 3), soft cliffs and sandy beaches, with the Suffolk coast (in particular) comprising a mix of soft points/embayments and hard points (natural and man-made) (Brooks and Spencer, 2010; Burningham and French, 2016). Longshore sediment transport, within sediment cells, is a dominant characteristic of the coastal processes at work in East Anglia. Past attempts to protect stretches of coast have disrupted long-shore sediment pathways, resulting in stretches of coast adjacent to protected areas becoming sediment starved and more vulnerable (Evans et al., 2004; Environment Agency, 2010). Sediment loss is a common unintended consequence, on the wider coastline, resulting from implementation of 'sea defences', such as sea walls and groynes (Walkden and Rossington, 2009). This has influenced government policy in England. Overstrand in North Norfolk provides an example of this, where the sea wall, timber groynes and revetments are said to block sediment transport to downcast beaches (Brennan, 2007).

The UK has a high number of critical infrastructure sites located on its North Sea coast (Brown et al., 2014). Within the region of East Anglia there are many critical national infrastructure sites that are threatened, including Bacton Gas terminal (Vikolainen et al., 2017), through which a third of the UK gas supply flows, and the Sizewell Nuclear power plant (Armstrong et al., 2015) (one of the largest investment areas in the UK). There are many locations in the South East of England where justification is seen to exist for continued use of hard adaptation measures (Jones et al., 2015); this includes infrastructure choke points in East Anglia and densely populated urban areas. Yet a number of 'softer' measures have also been implemented in the region. Rupp-Armstrong and Nicholls (2007, p.1422) have outlined how 'regional assessments of Suffolk and Norfolk' have suggested there is large potential for Managed Realignment producing a 'net gain in inter-tidal habitats' and that 'the majority of Managed Realignment sites are situated on England's East Coast in particular East Anglia' where ' $30 \%$ of the UK salt marsh habitat' is located. Another soft adaptation measure, termed the 'Sand Engine', originating in the Netherlands, is also currently being considered for implementation in the coastal area surrounding Bacton Gas terminal (Vikolainen et al., 2017). 


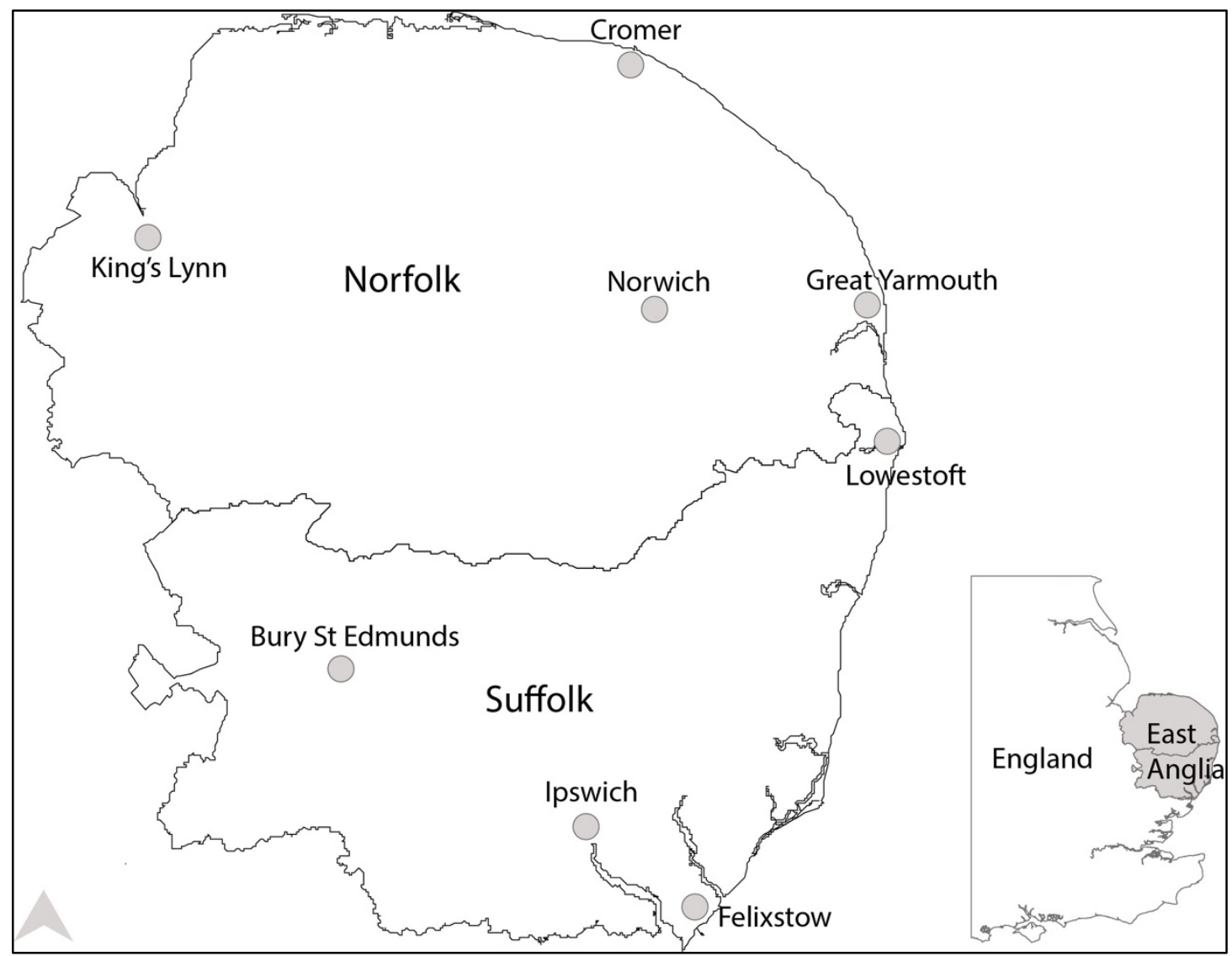

Figure 2: Map of East Anglia (courtesy of www.openstreetmap.org)

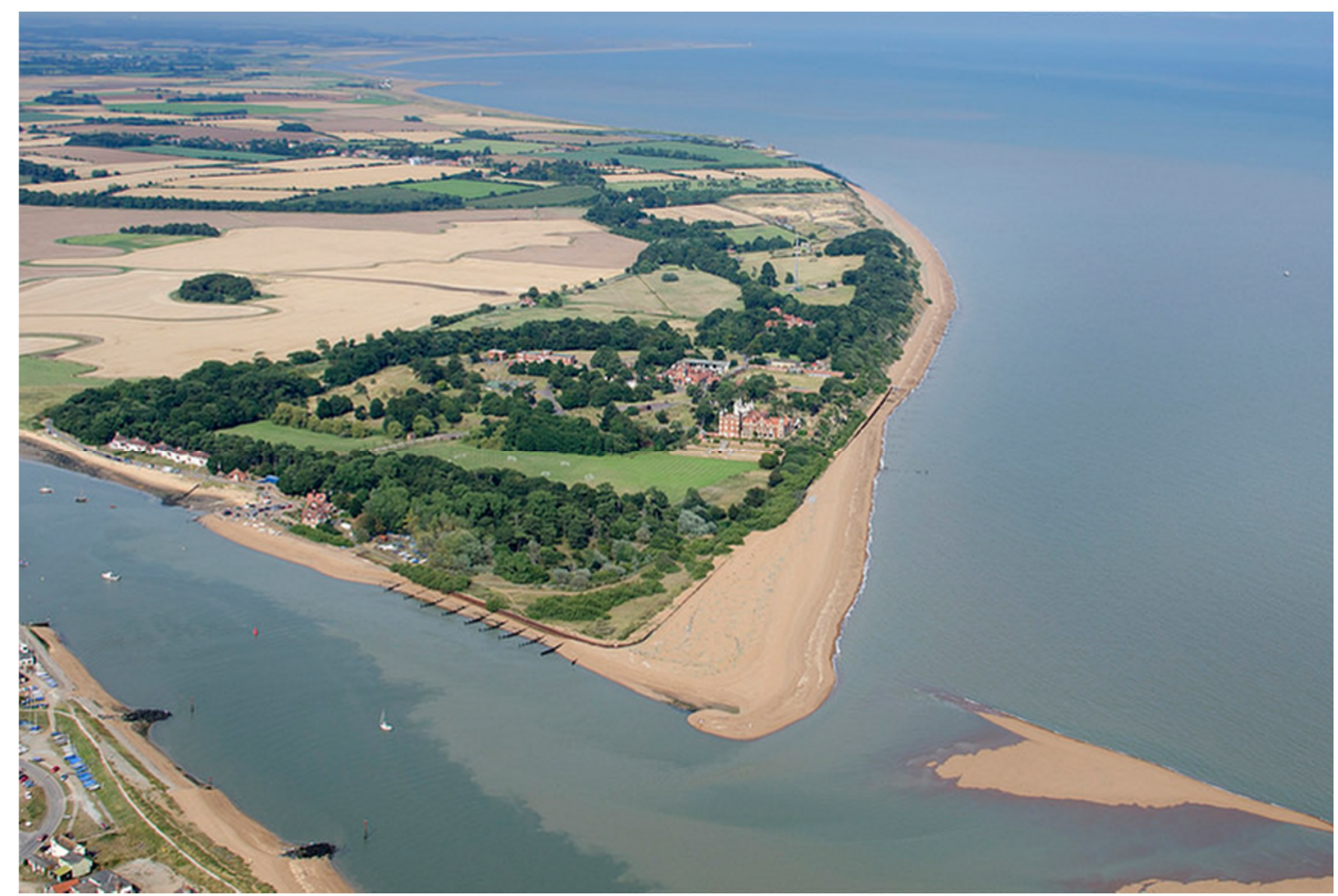

Figure 3: Low lying coastal region of Bawdsey in East Anglia (photo courtesy of www.mike-page.co.uk)

In East Anglia, a broad span of projects of note have been undertaken focusing on coastal change and risk, combining stakeholders and multiple academic organisations. Two significant studies, which have partially focussed on the area have been the 'Tyndall Coastal Simulator' project (Mokrech et al., 2011) and subsequently 'iCOASST' (Nicholls et al., 2012). Wider pan-European studies have been completed, 
incorporating the region, such as RISC-KIT (van Dongeren et al., 2014). A further initiative is MKEN (Marine Knowledge Exchange Network) (The University of East Anglia). The network focuses on knowledge and research for the coastal domain in East Anglia and is based at the University of East Anglia.

In terms of physical environmental data collection, an ongoing collaborative survey and mapping initiative exists in East Anglia, entitled the 'Anglian Coastal Monitoring Group' (East Anglian Coastal Group). This group, founded in 1987, was the first regional mapping program in the UK. It includes representatives from local authorities, the EA and Natural England and has been involved with coordination of survey activities for the coast of East Anglia, resulting in accrual of 20 years' worth of data. Data derived by the group is valuable as it informs coastal management decisions. As such the rapid progress being made in making coastal data available Open Source can present valuable opportunities for groups such as this.

\subsection{East Anglian Data Repository Sources and Outputs}

The data repository and GIS detailed within this case study is intended to serve the production of outputs supporting both MKEN, the Anglian Coastal Monitoring Group, Coastal Partnership East (District Council level), and policy makers at a national scale (DEFRA/HM Government). Figure 4 illustrates some of the input sources and potential recipients of outputs related to this GIS data repository.

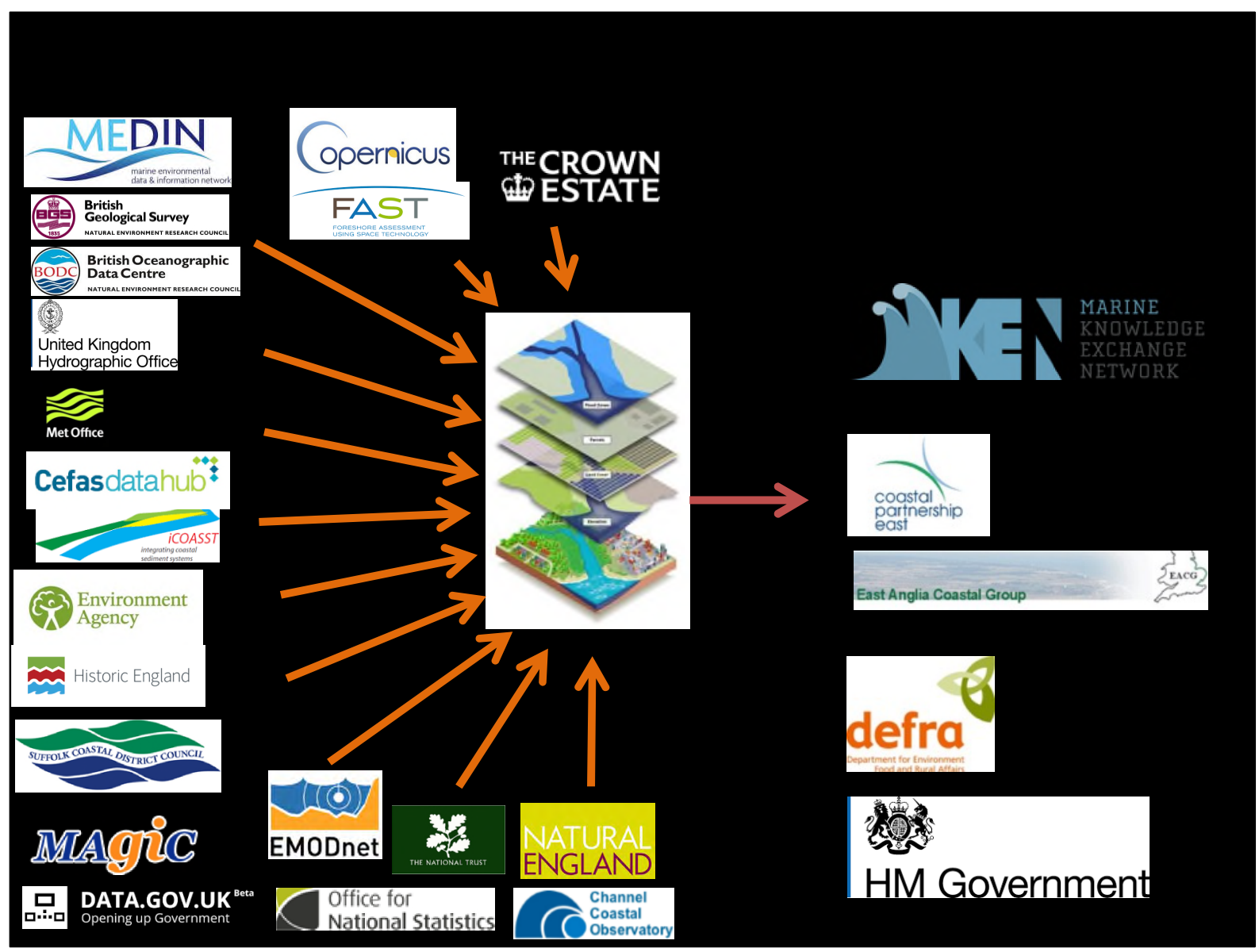

Figure 4: Data Sources and Outputs for an East Anglia Case Study

Within this case study, numerous data types have been linked to the sources outlined in Table 3 (and within the supplementary material, available online). This has enabled a broad range of data to be 
collated, representing physical environmental parameters, socio-economic indicators and demographic change, in line with a heterodox/holistic approach.

\subsection{Risk Evaluation -Conceptual Framework}

Evaluation of the various data sources outlined in Table 3, has revealed how data representing the three broad themes highlighted in Table 2 (environmental, social, and economic) are available for the case study area. Combining this data in a GIS project, enabled progressive stages of risk analysis to be undertaken. This analysis can be represented in incremental stages, characterised within a conceptual framework (Figure 5). First, data is brought together which represents a wide range of themes, enabling a holistic risk evaluation processes to be initiated. The second stage involves identification of vulnerability, to infrastructure, people, property, and the environment. A third stage relates to revealing impacts, for example, by comparing data for the same area but for different time periods, such as before and after storm events. Finally, a fourth stage involves identification of adaptation measures, and associated effects. These adaptation measures can relate to engineered features or natural processes. Analysis within Stage 4 can also involve evaluation of the consequences of installation or removal of adaptation measures. Within this process, drawing on a wide range of datasets can reveal wider associated factors, potentially missed given a narrower focus. The conceptual framework developed in Figure 5 highlights how Open Source data can be used within coastal management and especially in risk evaluations. The open sources for each of the data types referred to within the case study can be found through linking coastal management themes and data types, detailed in Figure 1, with the open sources listed in Table 3.

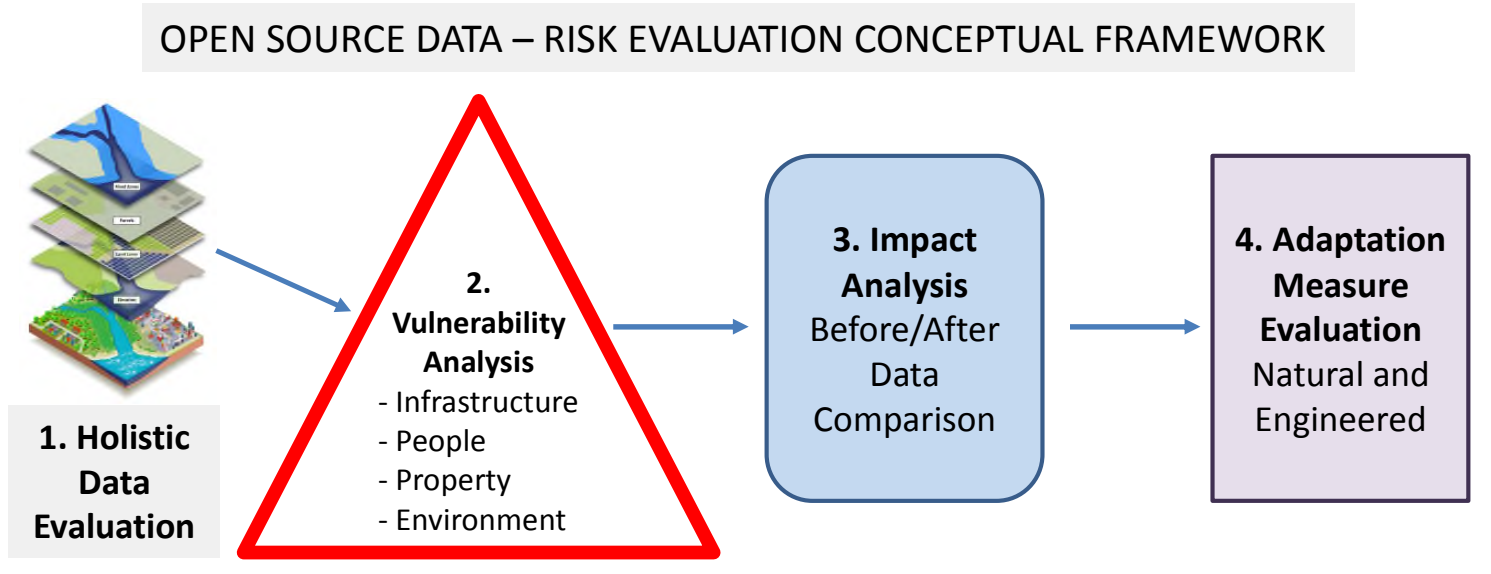

Figure 5: Conceptual Framework for Coastal Risk Evaluation using Open Source Data

\subsubsection{Conceptual Framework - Stage 1: Holistic Data Evaluation}

Heterodox and holistic approaches (Environment Agency, 2010), outlined in Section 2, refer to collating data from a wide array of different sources, some of these unconventional, representing natural processes, society and the economy. The methodology employed in creating the East Anglian GIS involved combining data obtained from a wide range of such sources. This data has included outputs from physical environmental monitoring projects, information related to humans who live on and use the coast, and trends such as land use change. Juxtaposing such diverse datasets using a geospatial mapping tool allowed relationships to be derived between the wide range of factors present within the region. Table 4 provides an indication of some of the datasets which were included within the East Anglian GIS. 
Table 4: Example of holistic data source used with the East Anglian GIS

\begin{tabular}{|c|c|c|c|}
\hline Data Type & Category & Source & Use \\
\hline \multirow[t]{6}{*}{ Environmental } & Coastal Monitoring & $\begin{array}{l}\text { CCO, EA, MEDIN (BGS, } \\
\text { BODC, UKHO), CEFAS }\end{array}$ & $\begin{array}{l}\text { Reveals geomorphological change, } \\
\text { indication of physical changes, trends, } \\
\text { oceanographic conditions, specie } \\
\text { distribution, pollution }\end{array}$ \\
\hline & Meteorological data & Met Office UK & Climate conditions, past and forecast \\
\hline & $\begin{array}{l}\text { Coastal Change } \\
\text { Forecasts }\end{array}$ & Academia, EA & $\begin{array}{l}\text { Outputs from studies and } \\
\text { assessments giving indications of } \\
\text { future impacts }\end{array}$ \\
\hline & Natural Capital & $\begin{array}{l}\text { FAST, EA, Natural } \\
\text { England, Copernicus }\end{array}$ & $\begin{array}{l}\text { Protective role offered by natural } \\
\text { capital and change in coverage }\end{array}$ \\
\hline & Land Based Hazards & BGS, EA & $\begin{array}{l}\text { Location of landfill sites and other } \\
\text { potential hazards/containments in } \\
\text { floodplains }\end{array}$ \\
\hline & Groundwater & BGS, EA & $\begin{array}{l}\text { Aquifer and groundwater sources, } \\
\text { their vulnerability to salinization }\end{array}$ \\
\hline \multirow[t]{7}{*}{$\begin{array}{l}\text { Socio-economic } \\
\text { Factors }\end{array}$} & $\begin{array}{l}\text { Population wealth } \\
\text { and health } \\
\text { distribution }\end{array}$ & ONS, Datashine & $\begin{array}{l}\text { Financial and physical ability of } \\
\text { populations to cope with coastal } \\
\text { hazard impacts }\end{array}$ \\
\hline & Deprivation & ONS, Datashine & $\begin{array}{l}\text { Spatialized indications of vulnerability } \\
\text { of populations }\end{array}$ \\
\hline & Housing & $\begin{array}{l}\text { ONS, Datashine, Aerial } \\
\text { imagery, EO data, } \\
\text { CEDA, Copernicus, } \\
\text { District Councils }\end{array}$ & $\begin{array}{l}\text { Enable assessments of proximity (and } \\
\text { density) of human settlements to } \\
\text { hazard prone locations }\end{array}$ \\
\hline & Property damage & District councils & $\begin{array}{l}\text { Evaluation of past impacts to local } \\
\text { populations }\end{array}$ \\
\hline & $\begin{array}{l}\text { Business and } \\
\text { services disruption }\end{array}$ & District Councils & $\begin{array}{l}\text { Impacts to local economy from } \\
\text { coastal hazards }\end{array}$ \\
\hline & $\begin{array}{l}\text { Infrastructure } \\
\text { locations }\end{array}$ & $\begin{array}{l}\text { OS, suppliers (such as } \\
\text { National Grid), } \\
\text { Copernicus, aerial } \\
\text { imagery (CCO, EA) }\end{array}$ & $\begin{array}{l}\text { Enable assessment of critical } \\
\text { infrastructure vulnerable to coastal } \\
\text { change and hazards }\end{array}$ \\
\hline & $\begin{array}{l}\text { Government Policy } \\
\text { for the Coast (SMP) }\end{array}$ & EA, District Councils & $\begin{array}{l}\text { Indication of implications of } \\
\text { government policy in relation to } \\
\text { future protection of coastal regions }\end{array}$ \\
\hline \multirow[t]{6}{*}{ Land Use } & Agricultural Data & $\begin{array}{l}\text { ONS, Natural England, } \\
\text { MAGIC }\end{array}$ & $\begin{array}{l}\text { Prime farmland, agricultural yields, } \\
\text { exposure of food/income sources to } \\
\text { flooding/erosion }\end{array}$ \\
\hline & Planning Permission & District Councils & $\begin{array}{l}\text { Reveals future land use change and } \\
\text { vulnerability }\end{array}$ \\
\hline & $\begin{array}{l}\text { Land use change in } \\
\text { coastal areas }\end{array}$ & $\begin{array}{l}\text { National Trust, } \\
\text { Copernicus, CCO, EA }\end{array}$ & Trends revealed in past changes \\
\hline & Habitats & $\begin{array}{l}\text { JNCC, Natural England, } \\
\text { MAGIC, EMODNET }\end{array}$ & $\begin{array}{l}\text { Natural capital, impacts and exposure } \\
\text { of flora/fauna, provision of ecosystem } \\
\text { services }\end{array}$ \\
\hline & $\begin{array}{l}\text { Archaeological and } \\
\text { cultural significant } \\
\text { areas }\end{array}$ & $\begin{array}{l}\text { OS, Historic England, } \\
\text { National Trust }\end{array}$ & $\begin{array}{l}\text { Restrictions placed on use of land, } \\
\text { listed areas }\end{array}$ \\
\hline & Urbanisation & $\begin{array}{l}\text { Aerial imagery, } \\
\text { Copernicus (EO data), } \\
\text { European Environment } \\
\text { Agency) }\end{array}$ & $\begin{array}{l}\text { Spread of population in to vulnerable } \\
\text { areas, loss of natural capital, potential } \\
\text { disruption of natural processes - } \\
\text { increasing risk }\end{array}$ \\
\hline
\end{tabular}




\begin{tabular}{|l|l|l|l|}
\hline & $\begin{array}{l}\text { Energy (renewables, } \\
\text { oil and gas, nuclear), } \\
\text { Offshore Aggregates }\end{array}$ & $\begin{array}{l}\text { Crown Estate, OGA, } \\
\text { BGS, OS }\end{array}$ & $\begin{array}{l}\text { Human use of seabed areas, presence } \\
\text { of critical infrastructure, energy } \\
\text { resources }\end{array}$ \\
\cline { 2 - 4 } & Coastal Adaptation & $\begin{array}{l}\text { EA, Copernicus, District } \\
\text { Councils, CCO }\end{array}$ & $\begin{array}{l}\text { Presence of coastal protection } \\
\text { structure, condition of these, impacts } \\
\text { on surrounding area }\end{array}$ \\
\hline
\end{tabular}

\subsubsection{Conceptual Framework - Stage 2: Vulnerability Analysis}

Drawing on the foundation of a diverse range of holistic data sources, highlighted in Table 4, enables more refined analysis, with location specific themes. In evaluating coastal risk, a first stage involves an assessment of vulnerability. Vulnerability can be further divided between that to infrastructure, people, property, and the environment, these themes are elaborated on in the following subsections. Environmental datasets form the basis of vulnerability analysis. A starting point for this process is therefore, identification of environmental hazards. To do this data is required which reveals past, current and future conditions. This can take the form of environmental sensor measurements, potentially including meteorological and oceanographic data, such as tide, wave heights, wind speeds, and modelling outputs giving projections of future conditions. Alongside this other important data are required detailing the stability of land, local geology, land heights, coastal processes, dominant sediment pathways, and the presence of natural barriers. This information can reveal how likely an area is to experience erosion or flooding, and allows risk hotspots to be identified. Combining this knowledge of natural processes with details of human activity (for example settlements, local populations, infrastructure, and value accumulation in coastal areas) can reveal proximity to hazards and fragile natural environments, which in turn exposes vulnerability.

\subsubsection{Infrastructure}

Coastal populations (and those further afield) are reliant on infrastructure, some of which is exposed to coastal hazards. This infrastructure can relate to transportation, energy, telecommunication, waste and water supply (aquifers). Varied datasets have been included within the GIS which enable critical infrastructure vulnerable to impacts from coastal hazards to be more holistically identified. In so doing, understanding potential complex and cascading risk associated with impacts to specific infrastructure. Within East Anglia some examples of such infrastructure are: Bacton Gas Terminal sited on an eroding cliff (Vikolainen et al., 2017); Lowestoft's Bascule Bridge - prone to flooding during tidal surge events; Felixstowe port -the UK's busiest container port, vulnerable to flooding and erosion; and Sizewell Nuclear power plant -vulnerable to flooding. Key road transport routes such as the A12, linking North and South Suffolk, can also be identified as vulnerable, particularly in the Blythburgh area. The A149, coast road linking East and West Norfolk, is another vulnerable stretch of road identified, where many areas are low enough to be flooded by a tidal surge event, and in the past road closures have been common. Aside from transport there are a number of vulnerable aquifers within the region, these can be identified using datasets from the British Geological Survey (BGS).

Spatial representation of risk to infrastructure can aid identification of more complex risk patterns, interdependencies and causal chains, where vulnerability of one asset can destabilise the whole system, resulting in more widespread risks. For example, vulnerability to Bacton Gas terminal, in Norfolk can translate to wider risks for households and businesses across the country, who both directly and indirectly rely on gas imports routed through this terminal. Land use change is another serious consideration when assessing vulnerability. Fortunately, there are many datasets that have been created by organisations such as Copernicus and the National Trust, which reveal how coastal land use has altered. Planning permission data is also available, permitting indications of future vulnerability, given patterns of urbanisation and shifts in industrial practices. Another factor worthy 
of consideration is the changing patterns of transitory human usage of coastal areas, for example traffic flows along coastal roads (obtained from DFT and Highways England), and changes in recreational use of coastal areas (obtained from the $\mathrm{MMO}$ and other sources). This information can assist identification of emerging vulnerabilities.

\subsubsection{People and property}

For the case study area, large Open Source datasets covering the entire region are available such as Lidar topography, aerial imagery, and EO satellite data. This data has been effectively combined with statistical information (from the ONS and other sources) detailing incomes, health, property types, population densities and distribution. This process has revealed exposed populations, potentially situated in flood plains or close to the edge of rapidly eroding cliffs. Walcott in Norfolk is an example of an exposed coastal village, where poor quality housing is sited on highly erodible material. Across the region of East Anglia statistical information such as that derived from Datashine (University College London) and the ONS exposes large disparities in wealth. As such, residents exposed to coastal risk vary in their ability to contribute to flood defences or finance repairs of damaged properties. This divide is evident, for example, between many locations in North Norfolk and more densely populated locations such as the city of Great Yarmouth. The latter has a higher proportion of households classed as deprived (University College London), as a result residents are more dependent on government support, rendering the area potentially more vulnerable.

\subsubsection{Environment}

Aside from vulnerability associated with human use of coastal areas, a major factor requiring consideration is vulnerability of ecosystems located in coastal regions. The hazards of flooding and coastal erosion both seriously impact natural ecosystems (and the related inherent functioning of the ecosystem goods and services). Impacts are also generated from human activity in coastal areas and the ocean. Overuse and degradation of maritime resources represents a significant concern, and landbased pollutants are a major threat to coastal ecosystems. Ultimately the coastal zone contains only a finite set of resources (Dyer and Millard, 2002) and these resources are rendered increasingly vulnerable due to a combination of unsustainable resource use and environmental degradation. In acknowledgement of this, large sections of the East Anglian coast have some form of environmental designation imposed on them. Many sources of habitat mapping data exist, which enable realisation of habitats situated in hazard prone areas. This includes land based and aquatic habitats. Coastal management groups, working in the area, represent multiple organisation which focus on stewardship of natural capital, flora and fauna. There is a wide range of datasets available (sources detailed in Figure 1 and Table 3) which enable vulnerable species and ecosystems to be identified, and thus considered within future shoreline management options.

\subsubsection{Conceptual Framework - Stage 3: Impact Analysis}

Comparison of datasets representing different temporal periods enables the impacts of coastal hazard events to be quantified. Physical impacts can be modelled by comparison of aerial imagery or EO datasets, for example. When combined with point cloud data, derived from Lidar, hydrographic and terrestrial surveys, this proves especially powerful in allowing visual representations of coastal change to be combined with quantification of change, derived, for example, from volumetric change calculations. This can indicate accurately beach loss and creation, cliff recession, loss of natural capital, and inundation by flood waters. The increasing availability of higher resolution EO data, collected more frequently, is especially powerful in enabling impacts of specific storm events (such as the 2013 East Coast Surge (Spencer et al., 2015)) to be revealed. In line with the holistic approach detailed above, this information quantifying physical impacts to coastal regions, can be combined with statistical data detailing the consequences to people, property and infrastructure. Records exist of financial loss, disruptions to business and services, impacts on human health and other societal consequences. This data has been made available from district councils, the ONS and other sources, 
such as the EA. Historic flood extents are also available from the EA, as shapefiles, which when combined with data showing locations of properties and infrastructure, form an effective way of communicating the extent of impacts. Numerous datasets are now also available as web-feeds, some of which are real-time feeds; this is especially beneficial to impact analyses and can enable live monitoring data to be incorporated into geospatial analysis.

\subsubsection{Conceptual Framework - Stage 4: Adaptation Measure Evaluation}

In managing environmental risk in coastal regions, it is crucial to understand the role which man-made and natural adaptations exert on the coast. Within East Anglia a broad range of coastal adaptation mechanisms have been identified from the datasets brought together. Some of these are naturally occurring coastal buffers, such as barrier beaches and salt marshes, whilst others are man-made, hard adaptations, such as groynes and breakwaters. Also, easily identifiable are a number of 'soft' adaptation measures, which have also been implemented. Freely available temporal data such as aerial imagery, Lidar and habitat data, covering defined time periods, can assist in identifying habitats which act as natural barriers and reveal important changes in regions where adaptations are sited, thus aiding an evaluation of the role they could play.

Future coastal management strategies are reliant on information revealing the suitability of adaptation methods to specific locations. The benefits of a holistic approach to this, is that consideration can be given to the wide range of factors integral to these decisions. For example, a starting point can involve consideration of data relating to current SMP designation of coastal regions (available from the EA), detailing whether the current shoreline will be maintained, left or realigned. Given present and planned land use, there are important implications of these decisions. Therefore, it is essential to include data detailing properties and infrastructure situated in coastal areas prone to flooding or erosion. By combining this information with projections of future coastal change, derived from modelling outputs, more representative assessments can be made of the suitability of planned adaptation options.

Identification of critical infrastructure, as detailed above, is a core concern when making decisions on suitability of adaptation methods. Certain sites are deemed critical (such as infrastructure choke points) and should be defended, whilst other sites may actually benefit from processes such as Managed Realignment, (e.g. Hazlewood marshes in Suffolk (BBC, 2014)) which can result in the creation of valuable habitats, and restoration of ecosystem services, such as nitrogen and carbon capture (Mckew et al., 2013).

Impacts arising from implementation of past adaptation measures, are also of concern, as is destruction of natural barriers, as a result of urbanisation and settlement construction. The wide range of physical datasets available for the case study area has enabled these impacts to be revealed. For example, it is possible to pinpoint where sediment loss could have resulted, from the installation of hard defences or removal of natural capital which offered protective capacity. East Anglia bene- fits from an extensive archive of physical monitoring data, which when brought together has exposed correlations between construction or removal of adaptations and coastal change. This final stage of the conceptual framework highlighted well, how starting with a base of holistic, varied datasets has enabled vulnerability to be revealed, impacts to be quantified and finally can allow the most appropriate adaptation methods to be selected. Given this, the conceptual framework detailed in Figure 5 could prove a valuable addition to risk-based decision-making processes for coastal areas.

\section{Conclusion}

Coastal management is a complex field, which can be simplified through access to information, contributing to raising awareness of the diverse range of factors present within coastal zones. This paper has revealed how a great diversity of Open Source data now exists, able to address the multiple 
themes constituting the remit of a coastal manager. Drawing on such a diverse range of sources can remove ambiguity in judgements made on important matters in coastal areas. Data is held by a wide range of organisations; this paper has outlined 34 potential sources of open data for the UK coast. The UK is at the forefront of making public sector data available as Open Source (so has been used as an example within this paper). However similar data are rapidly becoming available for coastal regions globally (some of which are referred to). The process of assembling and analysing such vast stores of information encapsulates knowledge and can generate fresh insight. Through focusing on the case study of East Anglia, a conceptual framework has been developed, to assist in maximising the potential value of drawing together Open Source data for the coast, as part of a risk evaluation process. When attempting to apply this methodology to case studies in other part of the world, the main limiting factor, constraining its application, must be noted as the availability and quality of Open Source data. However, vast stores of data are rapidly becoming available Open Source. This has been recognised to provide decision-makers with a broader knowledge base to draw on, covering environmental, social and economic factors, when formulating plans for coastal areas.

\section{Acknowledgements}

The authors acknowledge the Coastal Partnership East, Great Yarmouth Borough, North Norfolk, Suffolk Coastal and Waveney District Councils and, in particular, Mr Bill Parker, for input and guidance to this work. British Geological Survey, in particular Anna Harrison and Katherine Lee, are acknowledged for their guidance. Timothy Brewer of Cranfield University is acknowledged for guidance and support provided.

This work was supported by the UK Natural Environment Research Council [NERC Ref: NE/M009009/1], Suffolk Coastal District Council [VGP/00043027], and the British Geological Survey [GA/16S/010]. 


\section{References}

Anderson, R., 1991. Information and systems. J. Appl. Syst. Anal. 18, 57-60.

Armstrong, J., Wilby, R., Nicholls, R.J., 2015. Climate change adaptation frameworks: an evaluation of plans for coastal Suffolk, UK. Nat. Hazards Earth Syst. Sci. 15, 2511-2524.

http://dx.doi.org/10.5194/nhess-15-2511-2015.

BBC, 2014. Aldeburgh Nature reserve Becomes Salt Marsh after Floods. http://www.bbc. com/news/uk-england-suffolk-29129103 (Accessed 9 November 2017).

Brennan, R., 2007. the North Norfolk coastline: a complex Legacy. Coast. Manag. 35, 587-599. http://dx.doi.org/10.1080/08920750701593428.

Brooks, S.M., Spencer, T., 2010. Temporal and spatial variations in recession rates and sediment release from soft rock cliffs, Suffolk coast, UK. Geomorphology 124, 26-41. http://dx.doi.org/10.1016/j.geomorph.2010.08.005.

Brown, I., 2006. Modelling future landscape change on coastal floodplains using a rule- based GIS. Environ. Model. Softw. 21, 1479-1490. http://dx.doi.org/10.1016/j. envsoft.2005.07.011.

Brown, S., Hanson, S., Nicholls, R.J., 2014. Implications of sea-level rise and extreme events around Europe: a review of coastal energy infrastructure. Clim. Change 122, 81-95. http://dx.doi.org/10.1007/s10584-013-0996-9.

Burningham, H., French, J., 2016. Shoreline - Shoreface Dynamics on the Suffolk Coast. Channel Coastal Observatory, National Network of Coastal Monitoring Programmes of

England, (n.d.) https://www.channelcoast.org/, (Accessed 17 March 2018).

Columbia University, Marine Geographic Data System (MGDS), (n.d.). http://www. marinegeo.org/index.php, (Accessed 17 March 2018).

Cooper, J.A.G., McKenna, J., 2009. Boom and bust: the influence of macroscale eco- nomics on the World's coasts. J. Coast. Res. 253, 533-538. http://dx.doi.org/10. 2112/09A-0001.1.

Copernicus, Copernicus Open Access Hub, (n.d.). https://scihub.copernicus.eu/, (Accessed 16 September 2017).

Data.GO.KR, No Title, (n.d.). https://www.data.go.kr/e_main.jsp\#/L21haW4, (Accessed 16 September 2017).

Data.gouv.fr, Open platform for French public data, (n.d.). https://www.data.gouv.fr/ en/, (Accessed 16 September 2017).

Data.gov.uk, (n.d.). https://data.gov.uk/, (Accessed 17 March 2017).

Data.gov.uk, Environment Agency, (n.d.). https://data.gov.uk/publisher/environment- agency, (Accessed 16 September 2017).

Data.Gov, The home of the U.S. Government's Open Data, (n.d.), https://www.data.gov, (Accessed 17 March 2018).

Dávila, O.G., Stithou, M., Pescaroli, G., Pietrantoni, L., Koundouri, P., Díaz-Simal, P., Rulleau, B., Touili, N., Hissel, F., Penning-Rowsell, E., 2014. Promoting resilient economies by exploring insurance potential for facing coastal flooding and erosion: evidence from Italy, Spain, France and United Kingdom. Coast. Eng. 87, 183-192.

http://dx.doi.org/10.1016/j.coastaleng.2013.12.007.

Deeming, H., 2008. Increasing Resilience to Storm-surge Flooding: Risks, Trust and Social Networks. PhD. Lancaster University.

Defra, 2004. Making Space for Water: Developing a New Government Strategy for Flood and Coastal Erosion Risk Management in England. London

Defra, 2005. Making Space for Water: Taking Forward a New Government Strategy for Flood and Coastal Erosion Risk Management. London.

Defra, 2009. Appraisal of flood and coastal erosion risk management. A DEFRA policy statement. https://www.gov.uk/government/publications/appraisal-of-flood-and- coastal-erosion-riskmanagement-a-defra-policy-statement-june-2009.

DEFRA, 2011. Coastal Pathfinder Evaluation: An Assessment of the Five Largest Pathfinder Projects. 
A Final Report by Regeneris Consulting.

Dodds, W., 2009. An Evaluation of Coastal Risk Decision Making in England, Wales and Northern Ireland. Cardiff University. http://core.ac.uk/download/pdf/19397244. pdf (Accessed 30 May 2017).

Dyer, B., Millard, K., 2002. A generic framework for value management of environment data in the context of integrated coastal zone management. Ocean. Coast. Manag. 45, 59-75. http://dx.doi.org/10.1016/S0964-5691(02)00046-7.

East Anglian Coastal Group, Coastal Monitoring, (n.d.). http://www.eacg.org.uk/default_ monitoring.asp, (Accessed 16 September 2017).

Elkington, J., 1997. Cannibals with forks: the Triple Bottom Line of the 21st century of Business. Capstone, Mankanto.

EMODnet; European Marine Observation Data network, 2017, http://www.emodnet.eu/, (Accessed 17 March 2017).

Environment Agency, 2010. The Coastal Handbook: a Guide for All Those Working on the Coast. Bristol.

European Union, 2014. Directive 2014/89/EU of the European Parliment and of the Council of 23 July 2014 establishing a framework for maritime spatial planning. Off.

J. Eur. Union 257, 135-145. http://eur-lex.europa.eu/legal-content/GA/TXT/?uri= celex:32014L0089.

Evans, E.P., Ashley, R., Hall, J.W., Penning-Rowsell, E.C., Saul, A., Sayers, P.B., Thorne, C.R., Watkinson, A., 2004. Foresight Future Flooding. Scientific Summary. Future risks and Their Drivers, vol. 1 Office of Science and Technology, London.

Filatova, T., Veen, A., 2006. Microeconomic Motives of Land Use Change in Coastal Zone Area;: Agent Based Modelling Approach. http://doc.utwente.nl/61124/1/ Filatova07micro.pdf.

Filatova, T., Mulder, J.P.M., Veen, A., 2011. Coastal risk management: how to motivate individual economic decisions to lower flood risk? Ocean. Coast. Manag. 54, 164-172. http://dx.doi.org/10.1016/j.ocecoaman.2010.10.028.

GOV UK, Defra Announces Major Open Data Programme, (2017a). https://data.blog.gov. uk/2015/06/29/defra-announces-major-open-data-programme/, (Accessed 16 September 2017).

GOV UK, Open data for better outcomes, (2017b). https://quarterly.blog.gov.uk/2017/ 02/02/opendata-for-better-outcomes/, (Accessed 16 September 2017).

Government of Canada, Open Government Portal, (n.d.). http://open.canada.ca/en/ open-data, (Accessed 16 September 2017).

Harley, M.D., Valentini, A., Armaroli, C., Perini, L., Calabrese, L., Ciavola, P., 2016. Can an earlywarning system help minimize the impacts of coastal storms? A case study of the 2012 Halloween storm, northern Italy. Nat. Hazards Earth Syst. Sci. 16, 209-222. http://dx.doi.org/10.5194/nhess-16-209-2016.

HELCOM, HELCOM map and data service, (n.d.). http://www.helcom.fi/, (Accessed 16 September 2017).

HM Government Cabinet office UK, 2012. Open Data White Paper: Unleashing the Potential. https://data.gov.uk/library/open-data-white-paper.

IODC UNESCO, Ocean Biogeographic Information System (OBIS), (n.d.). http://www. iobis.org, (Accessed 17 March 2018).

IPCC, Data Distribution Centre, (n.d.), http://www.ipcc-data.org, (Accessed 17 March 2018).

Jones, N., Clark, J.R.A., Malesios, C., 2015. Social capital and willingness-to-pay for coastal defences in south-east England. Ecol. Econ. 119, 74-82. http://dx.doi.org/10.

1016/j.ecolecon.2015.07.023.

Keay, C.A., Hallett, S.H., Farewell, T.S., Rayner, A.P., Jones, R.J.A., 2009. Moving the national soil database for England and Wales (LandIS) towards INSPIRE compliance. Int. J. Spat. Data Infrastructures Res. 4, 134-155. http://dx.doi.org/10.2902/1725- 0463.2009.04.art8. 
Kron, W., 2013. Coasts: the high-risk areas of the world. Nat. Hazards 66, 1363-1382.

http://dx.doi.org/10.1007/s11069-012-0215-4.

Kullenberg, G., 2010. Human empowerment: opportunities from ocean governance.

Ocean. Coast. Manag. 53, 405-420. http://dx.doi.org/10.1016/j.ocecoaman.2010. 06.006 .

Lewis, M., Horsburgh, K., Bates, P., 2013. Modelling coastal flood risk in the data poor Bay of Bengal region. In: 13th Int. Work. Wave Hindcasting Forecast. 4th Coast. Hazard Symp., Banff, Canada, http://dx.doi.org/10.1007/s11548-012-0737-y.

Lewsey, C., Cid, G., Kruse, E., 2004. Assessing climate change impacts on coastal infra- structure in the Eastern Caribbean. Mar. Policy 28, 393-409. http://dx.doi.org/10. 1016/j.marpol.2003.10.016.

Mackay, S., Brown, R., Gonelevu, M., Pelesikoti, N., Kocovanua, T., laken, R., lautu, F., TuiafituMalolo, L., Fulivai, S., Lepa, M., Mackey, B., 2018. Overcoming barriers to climate change information management in small island developing states: lessons from pacific SIDS. Clim. Policy 0, 1-14. http://dx.doi.org/10.1080/14693062.2018. 1455573.

MAGIC; Multi-Agency Geographic Information for the Countryside, (n.d.). http://magic. defra.gov.uk/home.htm, (Accessed 17 March 2017).

MAREMAP; The Marine Environmental Mapping Program, (n.d.). http://www.maremap. ac.uk/index.html, (Accessed 17 March 2017).

Mckew, B.A., Dumbrell, A.J., Taylor, J.D., Mcgenity, T.J., Underwood, G.J.C., 2013. Differences between aerobic and anaerobic degradation of microphytobenthic bio- film-derived organic matter within intertidal sediments. FEMS Microbiol. Ecol. 84, 495-509. http://dx.doi.org/10.1111/1574-6941.12077.

MEDIN; The Marine Environmental Data and Information Network, (n.d.). http://www. oceannet.org/about_us/, (Accessed 17 March 2017).

MEDIN, About us, (n.d.). http://www.oceannet.org/about_us/, (Accessed 16 September 2017).

Misdorp, R., 2011. Climate of Coastal Cooperation. Leiden, the Netherlands. http:// www.coastalcooperation.net/part-0/index.htm.

Mokrech, M., Hanson, S., Nicholls, R.J., Wolf, J., Walkden, M., Fontaine, C.M., Nicholson- Cole, S., Jude, S.R., Leake, J., Stansby, P., Watkinson, A.R., Rounsevell, M.D. a, Lowe, J.A., Hall, J.W., 2011. The Tyndall coastal simulator. J. Coast. Conserv. 15, 325-335. http://dx.doi.org/10.1007/s11852-009-0083-6.

MPC Marine Planning Consultants, Marine Planning Consultants complete ElA for new coastal defence scheme., (n.d.). http://www.marineplanning.org.uk/news/article/? id=212, (Accessed 16 September 2017).

Nicholls, R., Bradbury, A., Burningham, H., Dix, J., Ellis, M., French, J., Hall, J., Karunarathna, H., Lawn, J., Pan, S., Reeve, D., Rogers, B., Souza, A., Stansby, P., Sutherland, J., Tarrant, O., Walkden, M., Whitehouse, R., 2012. iCOASST-integrating coastal sediment systems. Coast. Eng. Proc. 1, 100.

Nicholls, R.J., Dawson, R.J., Day, S.A. (Eds.), 2015. Broad Scale Coastal Simulation. Springer Netherlands, Dordrecht. http://dx.doi.org/10.1007/978-94-007-5258-0.

NOAA, National Centers for Environmental Information, (n.d.). https://www.ngdc.noaa. gov/, (Accessed 16 September 2017).

NOAA, NOAA Digital Coast, (n.d.). https://coast.noaa.gov/digitalcoast/data/home.html, (Accessed 17 March 2018).

Oasis Hub, (2018). https://oasishub.co, (Accessed 17 March 2018).

Open Data Institute, No Title, (n.d.), https://theodi.org/, (Accessed 17 March 2018).

OSPAR, OSPAR data and information management system (ODIMS), (n.d.). https:// odims.ospar.org/about/, (Accessed 16 September 2017).

Penning-Rowsell, E., Johnson, C., Tunstall, S., Tapsell, S., Morris, J., Chatterton, J., Green, C., 2005. The Benefits of Flood and Coastal Risk Management: a Manual of Assessment Techniques. 
http://dx.doi.org/10.1596/978-0-8213-8050-5.

Powrie, H.E.G., Shadbolt, N.R., Chessell, M., Decker, S., Chua, T., Hendler, J., Luczak- Roesch, M., Clegg, R., Stobart, R., Watson, J., Boumphrey, R., 2014. Foresight Review of Big Data. http://www.Irfoundation.org.uk/publications/bigdata.aspx.

Roberts, R.S., 2012. Economic Strategies for Coastal Disaster Risk- Reduction: a Case Study of Exmouth. PhD. Murdoch University, Western Australia.

Rodwell, L.D., Fletcher, S., Glegg, G.A., Campbell, M., Rees, S.E., Ashley, M., Linley, E.A.,

Frost, M., Earll, B., Wynn, R.B., Mee, L., Almada-Villela, P., Lear, D., Stanger, P., Colenutt, A., Davenport, F., Barker Bradshaw, N.J., Covey, R., 2014. Marine and coastal policy in the UK: challenges and opportunities in a new era. Mar. Policy 45, 251-258.

http://dx.doi.org/10.1016/j.marpol.2013.09.014.

Rosser, N.J., Petley, D.N., Lim, M., Dunning, S.A., Allison, R.J., 2005. Terrestrial laser scanning for monitoring the process of hard rock coastal cliff erosion. Q. J. Eng. Geol. Hydrogeol. 38363 LP-375. http://qjegh.lyellcollection.org/content/38/4/363. abstract.

Rova, S., Pastres, R., Zucchetta, M., Pranovi, F., 2018. Ecosystem services' mapping in data-poor coastal areas: which are the monitoring priorities? Ocean. Coast. Manag. 153, 168-175. http://dx.doi.org/10.1016/j.ocecoaman.2017.11.021.

Rupp-Armstrong, S., Nicholls, R.J., 2007. Coastal and Estuarine retreat: a comparison of the application of managed realignment in England and Germany. J. Coast. Res. 236, 1418-1430. http://dx.doi.org/10.2112/04-0426.1.

Slatcher, N., 2017. Monitoring coastal slope instability integrated time-series airborne laser scanning. Photography 58 (5), 23-26 Sea Technol. 58(2017) 23-26.

Smith, D.A., 2016. Online interactive thematic mapping: applications and techniques for socioeconomic research. Comput. Environ. Urban Syst. 57, 106-117. http://dx.doi. org/10.1016/j.compenvurbsys.2016.01.002.

Spencer, T., Brooks, S.M., Evans, B.R., Tempest, J.A., Möller, I., 2015. Southern North Sea storm surge event of 5 December 2013: water levels, waves and coastal impacts. Earth-Science Rev. 146, 120-145. http://dx.doi.org/10.1016/j.earscirev.2015.04. 002.

Stapelberg, R., 2010. Infrastructure systems interdependencies and risk informed decision making (RIDM): impact scenario analysis of infrastructure risks induced by natural, technological and intentional hazards. Analysis 6, 21-27. http://www.iiisci.org/ journal/CV\$/sci/pdfs/R105SQ.pdf.

The Australian Government, Data.gov.au (2018), https://data.gov.au, (Accessed 17 March 2018).

The Crown Estate, Marine Data Exchange, (n.d.). http://www.marinedataexchange.co. uk/, (Accessed 16 September 2017).

The European Commission, INSPIRE Knowledge Base, (n.d.). http://inspire.ec.europa. eu/, (Accessed 16 September 2017).

The Guardian, 2006. Free our data campaign. http://www.freeourdata.org.uk, Accessed date: 17 March 2018.

The LGA Coastal SIG, (n.d.). http://Igacoastalsig.com/position-statements/, (Accessed 16 September 2017).

The Lowestoft Journal, Bourne Leisure claims first round in legal battle over erosion at Norfolk beach, (n.d.). http://www.lowestoftjournal.co.uk/news/bourne-leisure- claims-first-round-inlegal-battle-over-erosion-at-norfolk-beach-1-4430340, (Accessed 16 September 2017).

The National Archives, Open Government Licence, (n.d.). http://www.nationalarchives. gov.uk/doc/open-government-licence/version/3/, (Accessed 16 September 2017).

The University of East Anglia, The Marine Knowledge Exchange Network (MKEN), (n.d.). http://www.uea.ac.uk/mken, (Accessed 16 September 2017).

Ubaldi, B., 2013. Open Government Data: towards Empirical Analysis of Open Government Data Initiatives. http://dx.doi.org/10.1787/5k46bj4f03s7-en. Paris. 
University College London, Datashine Census, (n.d). http://datashine.org.uk/, (Accessed 17 March 2018).

USGS, U.S. Geological Survey Coastal and Marine Geoscience Data System, (n.d.). https:// cmgds.marine.usgs.gov, (Accessed 17 March 2018).

van Dongeren, A., Ciavola, P., Viavattene, C., de Kleermaeker, S., Martinez, G., Ferreira, O., Costa, C., McCall, R., 2014. RISC-kit: resilience-increasing strategies for coasts - toolKIT. J. Coast. Res. 366-371. http://dx.doi.org/10.2112/si70-062.1.

Viavattene, C., Jiminez, J.A., Owen, D., Priest, S., Parker, D., Micou, A.P., Ly, S., 2015. Resilience-increasing Strategies for Coasts - Coastal Risk Assessment Framework Guidance Document.

Vikolainen, V., Flikweert, J., Bressers, H., Lulofs, K., 2017. Governance context for coastal innovations in England: the case of sandscaping in North Norfolk. Ocean. Coast. Manag. 145, 82-93. http://dx.doi.org/10.1016/j.ocecoaman.2017.05.012.

Villatoro, M., Silva, R., Méndez, F.J., Zanuttigh, B., Pan, S., Trifonova, E., Losada, I.J., Izaguirre, C., Simmonds, D., Reeve, D.E., Mendoza, E., Martinelli, L., Formentin, S.M.,

Galiatsatou, P., Eftimova, P., 2014. An approach to assess flooding and erosion risk for open beaches in a changing climate. Coast. Eng. 87, 50-76. http://dx.doi.org/10. 1016/j.coastaleng.2013.11.009.

Walkden, M., Rossington, K., 2009. Characterisation and Prediction of Large-scale Long Term Change of Coastal Geomorphological Behaviours Proof of Concept Modelling. http://copac.ac.uk/search?rn=19\&any=great+britain\&ti=coastal+erosion\&sort- order=ti,date.

World Wide Web Foundation, Open Data Barometer, (n.d.). http://opendatabarometer. org/dataexplorer/?_year=2015\&indicator=ODB\&lang=en, (Accessed 16

September 2017). 


\section{SUPPLEMENTARY MATERIAL}

This document provides supplementary material to accompany the article 'Opening up the Coast'. It provides a table giving the content of a data repository formed as part of the case study referred to, further details of Open Source Data Portals referred to in text, and a glossary of abbreviations used.

\section{Data Repository content}

Data sources and types listed in Table 1 are those which have been included within the data repository formed as part of the case study focusing on the coast of East Anglia in the UK. Numbering of data sources corresponds to that in Table 3, and Figure 1 in 'Opening up the Coast'.

Table 5: Data Repository Content

\begin{tabular}{|c|c|c|}
\hline No. & Data Source & Data Types \\
\hline 1 & District Councils & $\begin{array}{ll}\text { - } & \text { Stakeholder identification } \\
\text { - } & \text { Recreational use } \\
\text { - } & \text { Future infrastructure development } \\
\text { - } & \text { Planning Permission for coastal land (historic/current/future) } \\
\text { - } & \text { Impacts on people and property } \\
\text { - } & \text { Land Use Change } \\
\text { - } & \text { Population distribution and structure } \\
\text { - } & \text { Urbanisation/industrialisation } \\
\text { - } & \text { Resettlement locations (Pathfinder projects) } \\
\text { - } & \text { Ownership of the coast } \\
\text { - } & \text { Administrative boundaries } \\
\text { - } & \text { Beach cliff surveys (transects) } \\
\text { - } & \text { Critical communication and transport infrastructure } \\
\text { - } & \text { Key infrastructure at risk: roads, rail, ports, water, telecoms, undersea structures }\end{array}$ \\
\hline 2 & $\mathrm{CCO}$ & $\begin{array}{ll}\text { - } & \text { Coastal Monitoring } \\
\text { - } & \text { Aerial image analysis } \\
\text { - } & \text { Geomorphology } \\
\text { - } & \text { Loss/creation of beaches, erosion/accretion rates } \\
\text { - } & \text { Real-time ocean sensor data } \\
\text { - } & \text { Bathymetry } \\
\text { - } & \text { Topography (including point cloud laser scanning of beaches) } \\
\text { - } & \text { Outputs from academic projects (e.g. iCOASST) }\end{array}$ \\
\hline 3 & MET Office & $\begin{array}{l}\text { - Meteorological sensor network } \\
\text { - Weather/Climate data }\end{array}$ \\
\hline 4 & UKHO & $\begin{array}{ll}- & \text { Bathymetry } \\
- & \text { Near shore navigation routes }\end{array}$ \\
\hline 5 & BODC & $\begin{array}{ll}\text { - } & \text { Water Quality } \\
\text { - } & \text { Oceanographic sensor data (real time) } \\
\text { - } & \text { Tidal data } \\
\text { - } & \text { Fisheries/aquaculture monitoring } \\
\end{array}$ \\
\hline 6 & $\begin{array}{l}\text { British Geological } \\
\text { Survey }\end{array}$ & $\begin{array}{l}\text { - } \quad \text { Geomorphological stability of the land, subsidence } \\
\text { - } \quad \text { Categorisation of coastal risk based on geological properties } \\
\text { - } \quad \text { Coastal Geology } \\
\text { - } \quad \text { Point cloud laser scanning of beaches } \\
\text { - } \quad \text { Aquifers and groundwater } \\
\text { - } \quad \text { Offshore aggregate surveys }\end{array}$ \\
\hline 7 & CEFAS & $\begin{array}{ll}\text { - } & \text { Habitat mapping } \\
\text { - } & \text { Species distribution } \\
\text { - } & \text { Water quality } \\
\text { - } & \text { Ocean Sensor Data (Real-time) } \\
\text { - } & \text { Fisheries/aquaculture monitoring }\end{array}$ \\
\hline
\end{tabular}




\begin{tabular}{|c|c|c|}
\hline 8 & Historic England & $\begin{array}{ll}\text { - } & \text { Archaeological/culturally significant areas } \\
\text { - } & \text { Historic coastal maps - settlement information, coastal extents }\end{array}$ \\
\hline 9 & Natural England & $\begin{array}{l}\text { - } \quad \text { Habitat mapping, wetlands, specie distribution Species distribution } \\
\text { - } \quad \text { Protection offered by natural habitats }\end{array}$ \\
\hline 10 & Environment Agency & $\begin{array}{ll}\text { - } & \text { Coastal Monitoring } \\
\text { - } & \text { Aerial Image analysis } \\
\text { - } & \text { Real time tidal sensor network } \\
\text { - } & \text { Industrial pollutants } \\
\text { - } & \text { Location of contaminants/pollution sources in flood plains } \\
\text { - } & \text { Location of landfill and sewage sites } \\
\text { - } & \text { Beach Cliff Surveys (including transects/LIDAR/hydrography) } \\
\text { - } & \text { Loss/creation of beaches, erosion/accretion rates } \\
\text { - } & \text { River and estuary data } \\
\text { - } & \text { Coastal risk assessments } \\
\text { - } & \text { Key infrastructure at risk: roads, rail, ports, water, telecoms, undersea structures } \\
\text { - } & \text { Impacts on people and property } \\
\text { - } & \text { Urban and rural flooding extents (recorded and forecast) } \\
\end{array}$ \\
\hline 11 & DEFRA & $\begin{array}{ll}\text { - } & \text { Farming/Agriculture datasets } \\
\text { - } & \text { Ecosystem services }\end{array}$ \\
\hline 12 & The Crown Estate & $\begin{array}{ll}\text { - } & \text { Offshore Renewable Energy projects } \\
\text { - } & \text { Offshore aggregate extraction } \\
\text { - } & \text { Ownership of coast } \\
\text { - } & \text { Hydrographic survey data }\end{array}$ \\
\hline 13 & Copernicus (ESA) & $\begin{array}{ll}\text { - } & \text { Satellite EO data } \\
\text { - } & \text { Loss/creation of beaches, erosion/accretion rates } \\
\text { - } & \text { Land use change } \\
\text { - } & \text { Topography } \\
\text { - } & \text { Ocean properties }\end{array}$ \\
\hline 14 & MEDIN & $\begin{array}{l}\text { - } \quad \text { Links to Marine and geological data } \\
\text { - } \quad \text { Hydrographic surveys }\end{array}$ \\
\hline 15 & MAGIC & $\begin{array}{l}\text { - } \quad \text { Links to Environmental data } \\
\text { - } \quad \text { Land categorisation: protected, industry, urban, prime farmland } \\
\text { - } \quad \text { Land use/land use change } \\
\text { - } \quad \text { Marine habitat mapping, wetlands, specie distribution } \\
\text { - } \quad \text { Farming/Agriculture datasets }\end{array}$ \\
\hline 16 & $\begin{array}{l}\text { Intergovernmental } \\
\text { Panel on Climate } \\
\text { Change (IPCC) }\end{array}$ & - Climate change predictions \\
\hline 17 & $\begin{array}{l}\text { Academia } \\
\text { (e.g. iCOASST, } \\
\text { RISC-KIT, FAST) }\end{array}$ & $\begin{array}{l}\text { - } \quad \text { Aesthetic Valuations of the natural environment } \\
\text { - } \quad \text { Ecosystem services } \\
\text { - } \quad \text { Impacts generated by man-made coastal protection structures } \\
\text { - } \quad \text { Modelling Outputs based on various scenarios for the coast (inundation) } \\
\text { - } \quad \text { Change in protection offered by natural capital }\end{array}$ \\
\hline 18 & EMODNET & $\begin{array}{l}\text { - } \quad \text { Repository of coastal and ocean data from many sources, for Europe } \\
\text { - } \quad \text { Bathymetric charts } \\
\text { - } \quad \text { Marine habitat mapping, wetlands, specie distribution }\end{array}$ \\
\hline 19 & $\begin{array}{l}\text { Data.Gov.UK (web } \\
\text { portal) }\end{array}$ & $\begin{array}{l}\text { Access to public sector datasets, including: } \\
\text { - } \text { River and Estuary data } \\
\text { - } \text { Ownership of coast } \\
\text { - } \text { Future infrastructure development } \\
\text { - } \text { Tourism } \\
\text { - Human health } \\
\text { - } \text { Business activity } \\
\end{array}$ \\
\hline 20 & $\begin{array}{l}\text { Department for } \\
\text { Transport (DFT) UK }\end{array}$ & $\begin{array}{ll}\text { - } & \text { Traffic flow data/road use } \\
\text { - } & \text { Infrastructure choke points/critical transport infrastructure } \\
\text { - } & \text { Maritime and shipping statistics }\end{array}$ \\
\hline
\end{tabular}




\begin{tabular}{|c|c|c|}
\hline & $\begin{array}{l}\text { and Highways } \\
\text { England }\end{array}$ & $\begin{array}{ll}\text { - } & \text { Assessment of ports national importance } \\
\text { - } & \text { Key infrastructure at risk: roads, rail, ports, water, telecoms, undersea structures }\end{array}$ \\
\hline 21 & $\begin{array}{l}\text { The Office for } \\
\text { National Statistics }\end{array}$ & $\begin{array}{ll}\text { - } & \text { Port usage } \\
\text { - } & \text { Import/export data (ports) } \\
\text { - } & \text { Shipping cargo statistics } \\
\text { - } & \text { Assessment of ports' national importance } \\
\text { - } & \text { Employment data } \\
\text { - } & \text { Economic decline } \\
\text { - } & \text { Income data } \\
\text { - } & \text { Business activity } \\
\text { - } & \text { Human health } \\
\text { - } & \text { Population distribution and structure } \\
\text { - } & \text { Urbanisation/industrialisation } \\
\text { - } & \text { Tourist numbers -footfall } \\
\text { - } & \text { Includes NOMIS -Official labour market statistics } \\
\end{array}$ \\
\hline 22 & $\begin{array}{l}\text { Datashine (University } \\
\text { College London) }\end{array}$ & $\begin{array}{l}\text { - } \quad \text { Socio-economic data related to } 2011 \text { Census } \\
\text { - } \quad \text { Spatialized indices of economic decline } \\
\text { - } \quad \text { Puman health } \\
\text { - }\end{array}$ \\
\hline 23 & $\mathrm{ABI}$ & - Insurance industry datasets \\
\hline 24 & UK OGA & - $\quad$ Oil and Gas data /infrastructure, surveys \\
\hline 25 & Land Registry & $\begin{array}{ll}\text { - } & \text { Land/property prices } \\
\text { - } & \text { Land use } \\
\text { - Ownership of coast } \\
\text { - } & \text { Administrative boundaries } \\
\end{array}$ \\
\hline 26 & JNCC & $\begin{array}{ll}\text { - } & \text { Habitat mapping } \\
\text { - } & \text { Species distribution } \\
\text { - } & \text { Industrial pollutants } \\
\text { - } & \text { River and estuary data } \\
\text { - } & \text { Protection offered by natural habitats } \\
\text { - } & \text { Marine conservation zones } \\
\end{array}$ \\
\hline 27 & NOAA NCEI & $\begin{array}{l}\text { - } \quad \text { Global datasets for coasts and oceans } \\
\text { - Some limited data for case study site -East Anglia }\end{array}$ \\
\hline 28 & Ordnance Survey (OS) & $\begin{array}{ll}\text { - } & \text { River and Estuary location data } \\
\text { - } & \text { Administrative boundaries } \\
\text { - } & \text { Cadastral maps } \\
\text { - } & \text { Energy Infrastructure }\end{array}$ \\
\hline 29 & MMO & $\begin{array}{ll}\text { - } & \text { Marine Spatial Planning } \\
\text { - } & \text { Fis Data } \\
\text { - } & \text { Recreational use of the coast } \\
\text { - } & \text { Industrial pollutants } \\
\text { - } & \text { Water quality } \\
\text { - } & \text { Marine conservation zones } \\
\end{array}$ \\
\hline 30 & $\begin{array}{l}\text { Centre for Ecology } \\
\text { and Hydrology }\end{array}$ & $\begin{array}{l}\text { - Host the National River Flow Archive (NRFA), Environmental Information Centre, } \\
\text { Environment change network, and the biological records centre } \\
\text { - Broad data types associated with each data centre included }\end{array}$ \\
\hline 31 & The National Trust & - $\quad$ Coastal land use and land access to national trust land \\
\hline 32 & National Grid & - $\quad$ Energy Infrastructure \\
\hline 33 & $\begin{array}{l}\text { European } \\
\text { Environment } \\
\text { Agency }\end{array}$ & $\begin{array}{ll}- & \text { Europe wide Environmental data downloads } \\
\text { - } & \text { Land Use } \\
\text { - } & \text { Pollution } \\
\text { - } & \text { Water }\end{array}$ \\
\hline 34 & CEDA Archive & $\begin{array}{l}\text { - } \quad \text { The atmospheric and EO data centre for NERC for the UK } \\
\text { - Datasets including: climate, composition, observations and NWP data, and various } \\
\text { EO datasets, including airborne and satellite data and imagery }\end{array}$ \\
\hline
\end{tabular}




\section{Open Source Data Portals}

\section{MEDIN}

MEDIN [1] is an open partnership, representing government departments, research institutions and private companies. MEDIN hosts Data Archive Centres (DACs), providing long-term data management and addressing many of the data issues noted, such as data format and common metadata standards. An example of one of the accredited DACs, is the 'Offshore Geolndex' that is hosted by British Geological Survey (BGS), for geology, geophysics, backscatter and geomorphological data [2].

\section{MAGIC}

The MAGIC website serves as a similar interactive geospatial environmental data portal as MEDIN. Its scope is broader than MEDIN and the data it makes available covers rural, urban, coastal and marine environments. MAGIC provides geographic information about the natural environment from across government; It is a public-sector collaboration, with Natural England managing the service under the direction of a steering group representing the partnership organisations [3].

\section{MAREMAP}

MAREMAP is a similar initiative to MEDIN and MAGIC, relating to the research community and marine mapping. MAREMAP combines seafloor geological, habitat mapping and model outputs with other data layers [4]. MAREMAP is jointly led by a group of research organisations including BGS and the National Oceanography Centre (NOC). The service not only presents existing maps, but also aims to create a new generation of mapping, which will be made available online. In line with INSPIRE [5], the objectives of MAREMAP's seafloor mapping activities include coordinating efforts of its associated data custodians, to avoid duplication of activities.

\section{The CCO}

The Channel Coastal Observatory (CCO) has extensive data holdings derived from environmental sensor technology. The CCO runs a network of regional coastal monitoring programmes and, operating in partnership with the EA and local authorities, is funded by DEFRA [6]. Their data holdings are also made available as Open Source, focussing on the physical attributes of the coast and near shore waters, such as: topographic, bathymetric, hydrodynamic and remote sensing data [4].

\section{CEFAS -BODC}

In addition to the $\mathrm{CCO}$, the BODC and the Centre for Environment, Fisheries and Aquaculture Science (CEFAS) also both provide a wide range of Open Source data relating to physical oceanographic variables; the BODC being one of the MEDIN DACs.

\section{The Environment Agency (EA)}

The EA is another significant source of coastal data and, including: Lidar topography, bathymetry, surveys of flood protection structures and flood risk assessments.

\section{The Crown Estate}

Another valuable source is the Crown Estate's, Marine Data Exchange [7], providing access to survey data and reports collated during the planning, building and operation of offshore renewable energy projects. The Crown Estate serves the role of trustee for these data, sharing the information to promote research and innovation.

\section{HELCOM}

HELCOM [8] (Helsinki Commission - Baltic Marine Environment Protection Commission) has been running for over four decades, involving an intergovernmental collaboration, tasked with protecting the marine environment in the Baltic Sea from pollution. HELCOM operates a map and data service, 
providing an open access portal similar to those described for the UK, containing maritime spatial data at a regional scale. The system boasts a comprehensive web-mapping interface, in which data relating to many of the coastal management themes detailed in Table 1 in 'Opening up the Coast', can be displayed and downloaded.

\section{OSPAR}

OSPAR is a comparable initiative, focussing on the North-East Atlantic, involving 15 governments from the EU. OSPAR host a Data Information Management System (ODIMS) [9], another online geospatial data access tool, making data collected through OSPAR's joint program available to the public. OSPAR view data management as critical to their work in assessing the state of the marine environment.

\section{EMODnet}

This involves more than 100 organisations, drawing on the notion of 'data stakeholders', and fostering an Open Source collaboration across national boundaries with stakeholders sharing their data. As in MEDIN, the project involves standardisation of marine data and harmonisation of metadata standards. The project is still in the early phases of development, with full establishment planned for 2020. Later phases involve creation of a high resolution, seamless, digital map for European waters, covering topography, geology, habitats and ecosystems. In 2015 a sub-project involving coastal mapping was initiated, involving physical mapping activities. UK partners to EMODnet include many of the organisational data sources detailed in Table 3 of 'Opening up the coast'.

\section{NOAA NCEI}

NOAA aims to realise a mission of discovery and access to data, through web-services, machine to machine services and web-mapping. As a result they hold the largest archive of marine data in the world [10]. The NCEI also offers data management expertise, including metadata training. In their combination of many different types of data, the services and expertise which the NCEI offer are worthy of note. 


\section{Glossary}

\begin{tabular}{|c|c|}
\hline AIS & Automatic Identification System \\
\hline BGS & British Geological Survey \\
\hline BODC & British Oceanographic Data Centre \\
\hline $\mathrm{CCO}$ & The Channel Coastal Observatory \\
\hline CEDA & Centre for Environmental Data Analysis \\
\hline CEFAS & The Centre for Environment, Fisheries and Aquaculture Science \\
\hline DAC & Data Archive Centre \\
\hline DEFRA & Department for Environment Food and Rural Affairs \\
\hline DFT & Department for Transport \\
\hline EA & The Environment Agency \\
\hline EDINA & European Community \\
\hline EMODnet & European Marine Observation Data network \\
\hline EO & Earth Observation \\
\hline ESA & The European Space Agency \\
\hline FAST & Foreshore Assessment using Space Technology \\
\hline GIS & Geographical Information Systems \\
\hline GNSS & Geographical Information System \\
\hline HELCOM & The Helsinki Commission- Baltic Marine Environment Protection Commission \\
\hline iCOASST & integrating COASTal Sediment Systems \\
\hline ICZM & Integrated Coastal Zone Management \\
\hline INSPIRE & Infrastructure for Spatial Information in Europe \\
\hline ISO & International Organisation for Standardisation \\
\hline JNCC & Joint Nature Conservation Committee \\
\hline LGA & Local Government Association \\
\hline LIDAR & Light Detection and Ranging \\
\hline MAGIC & Multi-Agency Geographic Information for the Countryside \\
\hline MAREMAP & The Marine Environmental Mapping Program \\
\hline MCZ & Marine Conservation Zone \\
\hline MEDIN & The Marine Environmental Data and Information Network \\
\hline MET & Meteorological \\
\hline MKEN & The Marine Knowledge Exchange Network \\
\hline MMO & The Marine Management Organisation (UK) \\
\hline MODIS & Moderate Resolution Imaging Spectroradiometer \\
\hline MPA & Marine Protected Area \\
\hline MSP & Maritime Spatial Planning \\
\hline NCEI & National Centre for Environmental Informatics (NOAA, USA) \\
\hline NERC & The National Environmental Research Council \\
\hline NOAA & National Oceanographic and Atmospheric Association (USA) \\
\hline OGC & Open Geospatial Consortium \\
\hline OGA & The Oil and Gas Authority \\
\hline ONS & The Office for National Statistics \\
\hline OS & The Ordnance Survey \\
\hline OSPAR & Oslo/Paris convention \\
\hline
\end{tabular}


(for the Protection of the Marine Environment of the North-East Atlantic)

REST Representational State Transfer (web services)

RISC-KIT

Resilience-increasing Strategies for Coasts-toolkit

SIG

Special Interest Group

SMP

Shoreline Management Plan

UKHO

The United Kingdom Hydrographic Office

WFS

Web Feature Service

WMS

Web Map Service 


\section{References}

[1] MEDIN; The Marine Environmental Data and Information Network, (n.d.). http://www.oceannet.org/about_us/ (accessed March 17, 2017).

[2] MEDIN, About us, (n.d.). http://www.oceannet.org/about_us/ (accessed September 16, 2017).

[3] MAREMAP; The Marine Environmental Mapping Program, (n.d.). http://www.maremap.ac.uk/index.html (accessed March 17, 2017).

[4] L.D. Rodwell, S. Fletcher, G.A. Glegg, M. Campbell, S.E. Rees, M. Ashley, E.A. Linley, M. Frost, B. Earll, R.B. Wynn, L. Mee, P. Almada-Villela, D. Lear, P. Stanger, A. Colenutt, F. Davenport, N.J. Barker Bradshaw, R. Covey, Marine and coastal policy in the UK: Challenges and opportunities in a new era, Mar. Policy. 45 (2014) 251-258. doi:10.1016/j.marpol.2013.09.014.

[5] European Commission, D2.8.III.3 Data Specification on Soil - Draft Technical Guidelines: INSPIRE Infrastructure for Spatial Information in Europe., (2013). http://inspire.ec.europa.eu/documents/Data_Specifications/INSPIRE_DataSpecificati on_SO_v3.0rc3.pdf.

[6] Environment Agency, The coastal handbook: A guide for all those working on the coast, Bristol, 2010.

[7] The Crown Estate, Marine Data Exchange, (n.d.). http://www.marinedataexchange.co.uk/ (accessed September 16, 2017).

[8] HELCOM, HELCOM map and data service, (n.d.). http://www.helcom.fi/ (accessed September 16, 2017).

[9] OSPAR, OSPAR data and information management system (ODIMS), (n.d.). https://odims.ospar.org/about/ (accessed September 16, 2017).

[10] J. Cartwright, J. Varner, S. McLean, Data Stewardship: How NOAA Delivers Environmental Information for Today and Tomorrow, Mar. Technol. Soc. Journa. 49 (2015) 107-111. 